\title{
Combinations of Hydrogels and Mesenchymal Stromal Cells (MSCs) for Cartilage Tissue Engineering-A Review of the Literature
}

\author{
Mike Wagenbrenner $^{1}$, Susanne Mayer-Wagner ${ }^{1}\left(\mathbb{D}\right.$, Maximilian Rudert $^{2} \mathbb{D}$, Boris Michael Holzapfel ${ }^{1}$ \\ and Manuel Weissenberger ${ }^{2, *}$
}

1 Department of Orthopaedics and Trauma Surgery, Musculoskeletal University Center Munich (MUM), University Hospital, LMU Munich, Marchioninistraße 15, 81377 Munich, Germany; mike.wagenbrenner@med.uni-muenchen.de (M.W.); susanne.mayer@med.uni-muenchen.de (S.M.-W.); m-rudert.klh@uni-wuerzburg.de (M.R.); direktion.opmr@med.uni-muenchen.de (B.M.H.)

2 Department of Orthopaedic Surgery, University of Würzburg, König-Ludwig-Haus, Brettreichstr. 11, 97074 Würzburg, Germany

* Correspondence: m-weissenberger.klh@uni-wuerzburg.de

check for updates

Citation: Wagenbrenner, M.; Mayer-Wagner, S.; Rudert, M.; Holzapfel, B.M.; Weissenberger, M. Combinations of Hydrogels and Mesenchymal Stromal Cells (MSCs) for Cartilage Tissue Engineering-A Review of the Literature. Gels 2021, 7, 217. https://doi.org/10.3390/ gels7040217

Academic Editor: Esmaiel Jabbari

Received: 14 October 2021

Accepted: 13 November 2021

Published: 16 November 2021

Publisher's Note: MDPI stays neutral with regard to jurisdictional claims in published maps and institutional affiliations.

Copyright: (c) 2021 by the authors. Licensee MDPI, Basel, Switzerland. This article is an open access article distributed under the terms and conditions of the Creative Commons Attribution (CC BY) license (https:/ / creativecommons.org/licenses/by/ $4.0 /)$.

\begin{abstract}
Cartilage offers limited regenerative capacity. Cell-based approaches have emerged as a promising alternative in the treatment of cartilage defects and osteoarthritis. Due to their easy accessibility, abundancy, and chondrogenic potential mesenchymal stromal cells (MSCs) offer an attractive cell source. MSCs are often combined with natural or synthetic hydrogels providing tunable biocompatibility, biodegradability, and enhanced cell functionality. In this review, we focused on the different advantages and disadvantages of various natural, synthetic, and modified hydrogels. We examined the different combinations of MSC-subpopulations and hydrogels used for cartilage engineering in preclinical and clinical studies and reviewed the effects of added growth factors or gene transfer on chondrogenesis in MSC-laden hydrogels. The aim of this review is to add to the understanding of the disadvantages and advantages of various combinations of MSC-subpopulations, growth factors, gene transfers, and hydrogels in cartilage engineering.
\end{abstract}

Keywords: hydrogels; osteoarthritis; cartilage defects; MSCs; cartilage regeneration; tissue engineering

\section{Introduction}

Osteoarthritis (OA) affects more than $10 \%$ of men and $18 \%$ of women worldwide and places an enormous socio-economic burden on health care systems worldwide, with the number of joint replacement surgeries projected to increase steadily [1-3]. OA is characterized by traumatic or degenerative lesions to hyaline cartilage, which is a highly specialized, avascular, and brady trophic tissue covering the surface of diarthrodial joints [4]. As a result, damage to hyaline cartilage or osteochondral lesions naturally results in lasting defects or the formation of inferior fibrocartilage, which is why surgical and regenerative treatment methods for cartilage repair have gained growing interest $[4,5]$.

Tissue engineering combines the use of growth factors, gene transfer, and biomaterials to optimize chondrogenic differentiation and maintenance of a chondrogenic phenotype in seeded cells.

Cell-based approaches, such as tissue engineering (TE), combine the use of chondrogenic growth factors, cells, and functional scaffolds to further optimize the treatment of cartilage defects (Figure 1) [6]. Multipotent mesenchymal stromal cells (MSCs) have emerged as a promising cell source for use in cartilage engineering [7-9]. MSCs carry a characteristic set of surface markers, grow plastic adherent, can be differentiated toward the osteogenic, adipogenic, and chondrogenic lineage in vitro, and have been shown to reside in various, easily accessible adult and human fetal tissues [10,11]. Multiple studies have proven the potential of MSCs and their secretome to promote the natural healing 
and new formation of cartilage tissue in vitro and in vivo [7,12]. Despite good in vitro and in vivo data, limitations to the use of MSCs include loss of transplanted cells upon transplantation, insufficient chondrogenic differentiation, osteogenic de-differentiation, chondrogenic hypertrophy, or failed integration in targeted defects $[4,13]$.

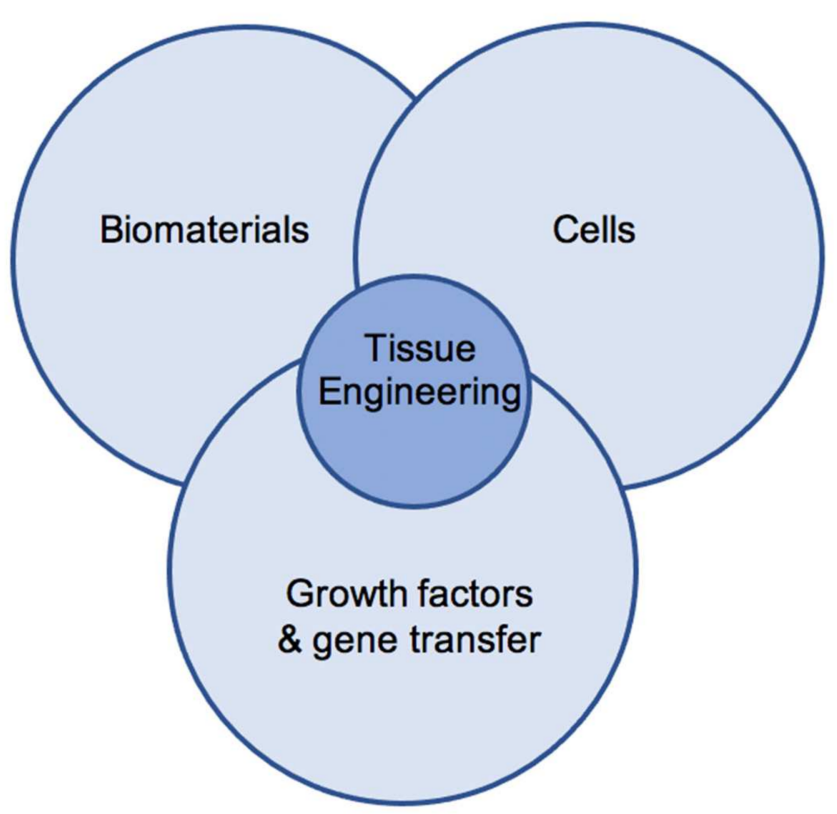

Figure 1. The triade of cartilage tissue engineering.

Therefore, to optimize clinical approaches for cell-based cartilage engineering, a beneficial 3D-microenvironment is necessary, containing a specific combination of biomaterials and growth factors to further enhance chondrogenesis in seeded cells. These biomaterials include hydrogels which are formed from various natural, synthetic, or modified polymers, retain large amounts of water and mimic the natural structure of hyaline cartilage to optimize chondrogenic differentiation and enhance cell functionality in MSCs [14]. Although the lack of mechanical stability, controlled biodegradability, or immunogenicity pose important challenges, hydrogels have been approved and successfully used in clinical approaches for the engineering of cartilage or intervertebral discs [12,15-17]. Cell-laden hydrogels can be manufactured according to defect composition, can be applied via minimal-invasive approaches, and may promote the repair of full-thickness cartilage defects [18]. In addition, the combination of natural and synthetic hydrogels and growth factors has been shown to enhance chondrogenic differentiation, maintain chondrogenic phenotype, and limit chondrogenic hypertrophy in seeded MSCs [14,15,19].

To further contribute to the field of cartilage engineering, we compared the use of MSCs and natural, synthetic, or modified hydrogels in this narrative review. Different types of hydrogels and subpopulations of MSCs were discussed and examined regarding specific advantages and disadvantages. Finally, we compared the combination of different MSCs, hydrogels, growth factors, or gene transfer for cartilage engineering to examine which composition offers the best results according to the current scientific literature.

\section{Results}

\subsection{Hydrogels in Cartilage Tissue Engineering}

Hydrogels consist of three-dimensional networks built from hydrophilic, polymeric biomaterials that are crosslinked through either covalent or physical bindings [20]. Current research focuses on the use of these three-dimensional hydrogels, which mimic the extracellular matrix (ECM) of hyaline cartilage to further optimize the treatment of cartilage defects. Both cell-free and cell-laden hydrogels have been used to treat cartilage defects [14,21-24]. Hydrogels used for the treatment of cartilage defects have to be highly 
biodegradable and biocompatible, possess strong water binding capacity enabling them to double their size through swelling, and present a certain porosity [20]. In addition, injectable hydrogels offer the advantage that they can be shaped to fit into individual-sized and -shaped cartilage defects $[14,25]$. Hydrogels can be divided into natural, synthetic, or modified natural hydrogels depending on the polymeric material they are built from. Natural hydrogels can be further separated into polysaccharide-based hydrogels formed from agarose (AG), alginate (AL), glycosaminoglycans (GAGs), and chitosan (CH), as well as protein-based hydrogels formed from collagen (COL), elastin (EL), gelatin (GEL), or other polymers [26]. Synthetic hydrogels are formed from polymers, such as polyethylene glycol (PEG), polyvinyl alcohol (PVA), or Poly(lactide-co-glycolide) (PLGA) [5,20,25,27]. In an approach to combine the benefits of both natural and synthetic hydrogels in the field of cartilage TE, modified hydrogels combining multiple polymers have been used $[26,28]$.

\subsection{Polysaccharide-Based Hydrogels in Cartilage Tissue Engineering}

GAGs can act as the base for polysaccharide-based hydrogels. An example for GAGs is hyaluronic acid (HA) which forms the most abundant component in the ECM of human hyaline cartilage and is also present in the ECM of other mammalian connective tissues where it mostly acts as a lubricant [26,29]. HA also contributes toward the resistance of hyaline cartilage toward shear and compressive forces. As a polymer, HA is strongly hydrophilic and highly biodegradable, possesses low adhesiveness, and provides a microenvironment similar to natural hyaline cartilage offering great conditions for the use in TE $[26,28]$. However, HA hydrogels can be hydrolyzed and therefore are unstable and easily degradable at body temperature.

Further, HA exhibits natural surface antigens that influence metabolism, inflammation, and proliferation in seeded chondrocytes [30].

HA hydrogels have been shown to increase the expression of chondrogenic marker genes and the synthesis of chondrogenic marker molecules in seeded MSCs and chondrocytes [8,31-33]. Hydrogels made from HA promoted early chondrogenesis in seeded MSCs by enhancing the synthesis of aggrecan and collagen type II, which is considered the gold standard for successful chondrogenic differentiation of MSCs in vitro. Hence, cell-laden HA hydrogels have been studied to form neocartilage tissue in vitro and in vivo [33,34].

To overcome the poor stability and control of biodegradability of HA hydrogels, they have been subject to various modifications, such as esterification of hydroxyl or carboxyl groups [35]. In addition, hydrophobic modification to hydrophilic HA can be made with polylactic acid (PLA) or ammine to create self-assembling and more modifiable, stable hydrogels [36]. Natural co-polymers derived from HA examined by Oldinski et al. showed modifiable viscoelasticity and porosity as well as biocompatibility and could be used for the treatment of osteochondral defects when used together with MSCs [6]. Further chondrocytes seeded in HA hydrogels modified with elastin-like protein showed enhanced expression of chondrogenic marker genes and GAG deposition with rising concentrations of HA [37]. Conjugation of sulfate groups to HA hydrogels allowed the slowing down biodegradation and led to a retention of seeded growth factors, thus enhancing chondrogenesis and preventing hypertrophic de-differentiation in encapsuled MSCs both in vitro and in vivo in animal OA models [38].

The natural polymer AL is a major component of cell walls in brown algae and capsules of certain bacteria [26]. The structure and mechanical properties of AL depend on the deposition of both monomers it is formed from [26]. AL can be physically crosslinked with divalent cations at room temperature, making it moldable and useful in the field of 3D bioprinting [39]. AL hydrogels also offer low costs and cytotoxicity, high biocompatibility, low immunogenicity, and low inflammatory characteristics leading to their frequent use in various biomedical applications [40]. However, AL hydrogels present low biodegradability despite insufficient mechanical stability in vivo and offer poor celladhesive properties $[14,26,41]$. 
MSC-laden AL hydrogels have been shown to promote the formation of repair tissue and regeneration of osteochondral defects in rabbit models [42]. Research has also shown that hypoxia mimicking AL hydrogels loaded with growth factors guide seeded cells toward a more chondrogenic phenotype while preventing osteogenic and hypertrophic dedifferentiation [43]. This effect may be enhanced when paired with shear and compression forces [42]. The combination of HA hydrogels with AL microspheres has been shown to retain the activity of transported growth factors and induce chondrogenesis in encapsulated MSCs both in vitro and in vivo [34].

In the field of cartilage TE, AL hydrogels have been linked with sulfate groups to promote a more functional tissue supporting cell growth and proliferation while enhancing the synthesis of cartilage-specific matrix proteins, such as collagen type II, in seeded chondrocytes [44].

AG offers great biocompatibility, water-solubility, is non-immunogenic, and possesses adjustable mechanical characteristics making it a widely used natural polymer in hydrogels for TE [45]. In addition, AG possesses thermally-reversible gelatin characteristics, is stable at body temperature, and soluble at temperatures over $65^{\circ} \mathrm{C}$-great conditions for the use in the minimal-invasive treatment of cartilage defects with the use of cell-laden hydrogels. Further, AG hydrogels provide a great balance between viscoelastic properties and stiffness with an adjustable water-binding capacity [14,45].

Research has shown that AG hydrogels support chondrogenic differentiation, synthesis of chondrogenic ECM, and the maintenance of chondrogenic phenotype in seeded cells when used for cartilage TE in vitro and in vivo [46-48]. However, AG may lead to less enhanced cell functionality, chondrogenic differentiation, and synthesis of cartilagespecific ECM components when compared to other polymers used in natural hydrogels for cartilage TE $[14,49]$.

$\mathrm{CH}$ is a polymer derived from chitin which is formed from D-glucosamine and Nacetyl-D-glucosamine and acts as the major component of the exoskeleton in various arthropods [26]. CH is cost-effective, acts bacteriostatic, is highly biodegradable and biocompatible, and has structural similarities to GAGs found in the ECM of hyaline cartilage, which contribute to the resistance of hyaline cartilage toward shear and compression forces $[14,26]$.

$\mathrm{CH}$ hydrogels have been shown to promote chondrogenesis and maintenance of chondrogenic phenotype in seeded cells as well as the deposition of cartilage-specific ECM components $[50,51]$. Sheeshy et al. showed that $\mathrm{CH}$ hydrogels may promote and maintain a superior chondrogenic phenotype while limiting hypertrophic de-differentiation in seeded MSCs in comparison to other natural polymers, such as AL or fibrin [48]. However, $\mathrm{CH}$ offers poor mechanical properties and is sensitive to temperature and $\mathrm{pH}$ changes, although some of these limitations can be overcome by modifications made to $\mathrm{CH}$ hydrogels [26,52].

\subsection{Protein-Based Hydrogels in Cartilage Tissue Engineering}

COL—especially COL type II-is the most abundant structural protein present in the natural ECM of hyaline cartilage. In addition, COL type II is known as the gold marker for successful chondrogenesis in MSCs in vitro [26,53]. However, hydrogels used for cartilage TE are often based on COL type I due to its high biocompatibility, vast safety, and clinical approval [53]. COL-based scaffolds also enhance cell functionality, phenotype maintenance, and cell proliferation upon the binding of cell receptors to natural ligands $[53,54]$.

We and others showed that COL type I hydrogels enhance chondrogenic differentiation and maintenance of chondrogenic phenotype in seeded MSCs in vitro, especially when paired with specific growth factors or gene transfer $[19,53,55]$. However, research has shown that both COL I-based scaffolds promote chondrogenesis in seeded MSCs with a possible superior synthesis of cartilage-specific ECM components but no significant differences in the expression of chondrogenic marker genes [55-57].

Major disadvantages when using COL type II hydrogels are their possible arthritogenic potential in combination with low clinical approval [53]. Limitations for pure 
COL type I-based hydrogels include limited mechanical properties, shrinkage, and limited induction of chondrogenic differentiation in seeded cells [53]. In addition, chondrocytes seeded in COL type I hydrogels underwent de-differentiation presented by decreased expression of chondrogenic marker genes, which could be due to contraction of COL at low concentrations promoting chondrocyte condensation [53,58].

GEL is a denatured form of COL produced by hydrolyzation [47]. GEL offers many advantages seen in COL hydrogels, such as high biocompatibility and biodegradability, as well as material-cell interaction enhancing cell functionality, chondrogenesis, and phenotype maintenance in seeded cells while showing better mechanic stability [59]. However, crosslinks in GEL hydrogels may offer inferior stability at body temperature requiring further modification with other polymers [60]. Hydrogels bioprinted from gelatinmethacryloyl (gelMA) and gellan gum have been shown to promote the production of cartilage-specific ECM components in seeded chondrocytes in vitro [61].

Silk fibroin is a new polymer used to form protein-based hydrogels for cartilage TE. Although silk fibroin hydrogels promote the synthesis of matrix proteins similar to the ECM in hyaline cartilage when loaded with chondrocytes and MSCs, this induction of chondrogenesis in seeded cells may be inferior to that seen in other natural hydrogels $[14,48]$.

\subsection{Synthetic Hydrogels in Cartilage Tissue Engineering}

Synthetic hydrogels are based on industrially manufactured polymers making them highly adjustable regarding porosity, biocompatibility, and biodegradability, as well as mechanically strong and reproducible. Research has shown that synthetic hydrogels alone or natural hydrogels modified with synthetic components may further improve cartilage TE [15]. However, synthetic polymers remain biologically inert, limiting their influence on cell functionality, as well as cell adherence, and are relatively expensive.

Due to its clinical approval, PEG remains a very popular synthetic polymer used for hydrogel formation. In addition, PEG can be easily modified while possessing great mechanical properties [15]. Chondrocytes embedded in PEG-HA hydrogels maintained their chondrogenic phenotype, showed increased functionality and limited hypertrophy [62]. PEG hydrogels modified with chondroitin sulfate may further limit hypertrophy during chondrogenesis in seeded MSCs [62]. Further, PEG-diacrylate (PEGDA) hydrogels have been shown to promote the formation of cartilage-specific ECM alone and in combination with seeded MSCs in vitro and have led to promising short-term results when used for the clinical treatment of cartilage defects in vivo [22]. In addition, PEGDA hydrogels modified with fibrinogen have been shown to enhance chondrogenic differentiation while limiting hypertrophic de-differentiation in seeded MSCs [63].

PLGA hydrogels modified with fibrin have been shown to promote the repair of full-thickness cartilage defects in rabbits when paired with MSCs and chondrogenic growth factors [64]. PVA also offers great properties for emulsification and cell adhesion and mechanical stability and performance similar to that of natural hyaline cartilage [65]. In addition, modified PVA-CH hydrogels promoted chondrogenic differentiation and the synthesis of cartilage-specific ECM components in seeded MSCs in vitro [66]. Poly(Nvinylcaprolactam) (PVCL) has also been used as a thermosensitive polymer in hydrogels for cartilage TE. Seeding cells in PVCL hydrogels led to successful chondrogenic differentiation accompanied by deposition of cartilage-specific ECM components as well as high cell viability [15].

\subsection{Comparison of Hydrogels in Cartilage Tissue Engineering}

In summary, natural hydrogels offer great properties for biocompatibility, biodegradability, cell viability, and the promotion of cell functionality by cell-material interactions (Table 1). Major disadvantages include low mechanical stability and high variability. In contrast, synthetic hydrogels offer highly tunable characteristics, such as porosity, viscoelasticity, and biodegradability. The specific advantages and disadvantages for protein- and polysaccharide-based hydrogels, as well as synthetic hydrogels, are listed in Table 1. 
Table 1. Advantages and disadvantages of selected natural and synthetic hydrogels for cartilage engineering.

\begin{tabular}{|c|c|c|}
\hline Protein-Based Hydrogels & Advantages & Disadvantages \\
\hline COL/GEL & $\begin{array}{l}\text { - } \quad \text { Collagen as a natural component of } \\
\text { the extracellular matrix of } \\
\text { hyaline cartilage } \\
\text { - } \quad \text { Immunomodulatory effects } \\
\text { - Increased cell adhesion } \\
\text { - } \quad \text { Suitable for bioprinting }\end{array}$ & $\begin{array}{l}\text { - } \quad \text { Poor mechanical properties } \\
\text { and stability } \\
\text { - } \quad \text { Temperature-sensitive } \\
\text { - } \quad \text { Limited delivery of growth factors }\end{array}$ \\
\hline Polysaccharide-based hydrogels & - Advantages & - Disadvantages \\
\hline HA & $\begin{array}{l}\text { - Natural component of the } \\
\text { extracellular matrix of } \\
\text { hyaline cartilage } \\
\text { Enhances cell functionality and } \\
\text { expression of chondrogenic } \\
\text { marker genes }\end{array}$ & - $\quad$ Low cell adhesive capacity \\
\hline $\mathrm{AL}$ & $\begin{array}{ll}\text { - } & \text { Strong mechanical properties } \\
\text { - } & \text { Suitable for bioprinting } \\
\text { - } & \text { Suitable for gene delivery }\end{array}$ & $\begin{array}{l}\text { - } \quad \text { Low biodegradability } \\
\text { - } \quad \text { Immunogenic response }\end{array}$ \\
\hline AG & $\begin{array}{ll}\text { - } & \text { Mechanical stability } \\
\text { - } & \text { Good viscoelasticity }\end{array}$ & - $\quad$ Limited support of cell functionality \\
\hline $\mathrm{CH}$ & $\begin{array}{ll}-\quad & \text { Suitable for delivery of } \\
\text { growth factors } \\
\text { - } \quad \begin{array}{l}\text { Similar structure as } \\
\text { glycosaminoglycans }\end{array} \\
\text { - } \quad \begin{array}{l}\text { Highly biodegradable and } \\
\text { biocompatible }\end{array}\end{array}$ & - $\quad$ Limited solubility \\
\hline Synthetic hydrogels & - Advantages & - Disadvantages \\
\hline PEG, PVA & $\begin{array}{ll}\text { - } & \text { Highly tunable biocompatibility } \\
\text { - } & \text { Mechanical properties } \\
\text { - } & \text { Partly promote chondrogenesis in } \\
\text { - } & \text { seeded cells } \\
\text { Mechanical properties }\end{array}$ & $\begin{array}{ll}\text { - } & \text { Biologically inert } \\
\text { - } & \text { Limited cell adhesive capacity } \\
\text { - } & \text { Himh costs } \\
& \end{array}$ \\
\hline
\end{tabular}

Precise description of the advantages and disadvantages presented by polysaccharide- and protein-based natural hydrogels as well as synthetic hydrogels. AL: alginate; AG: agarose; CH: chitosan; COL: collagen; GEL: gelatin; HA: hyaluronic acid; PEG: polyethylene glycol; PVA: polyvinyl alcohol.

Other than PEG, synthetic polymers are mostly not clinically approved, limiting their application in the field of cartilage TE. When comparing natural polymers for the fabrication of hydrogels, polysaccharide-based hydrogels based on HA and AG as well as protein-based COL hydrogels possess good mechanical stability, especially when modified with other natural and synthetic polymers, enhance cell functionality and differentiation by material-cell interaction, and offer good biocompatibility and biodegradability. All these natural hydrogels have shown promising results when used for cartilage engineering and repair both in vitro and in vivo $[14,33,45,53]$. Still, more research regarding newer natural and synthetic polymers as well as modified hydrogels is necessary to further determine the optimal hydrogel for cartilage TE.

\subsection{MSC-Laden Hydrogels for Cartilage Tissue Engineering}

Different kinds of cells and growth factors have been used to further enhance the pro-chondrogenic effects of hydrogels in the field of cartilage TE. Besides chondrocytes, multipotent or even pluripotent cells used in the field of cartilage TE include embryonic stem cells (ESCs), induced pluripotent stem cells (iPSCs), and different subpopulations of MSCs $[16,67]$. Interestingly, research has shown that different subpopulations of MSCs also possess different chondrogenic differentiation potential and vary in their set of surface 
antigens depending on the source of tissue they originate from [68-70]. In contrast to the pluripotent ESCs and iPSCs, multipotent MSCs raise fewer ethical concerns and can be isolated in large numbers from almost all vascularized adult and fetal tissues using a minimal invasive surgical approach. Therefore, MSCs have emerged as a promising cell source for cartilage TE. However, there remains disagreement regarding the optimal combination of MSCs and hydrogels as well as growth factors which is why this review focuses on recent advances in the combinations of these variables to further optimize cartilage TE (Figure 2).

\section{MSC-laden hydrogels for treatment of cartilage defects}

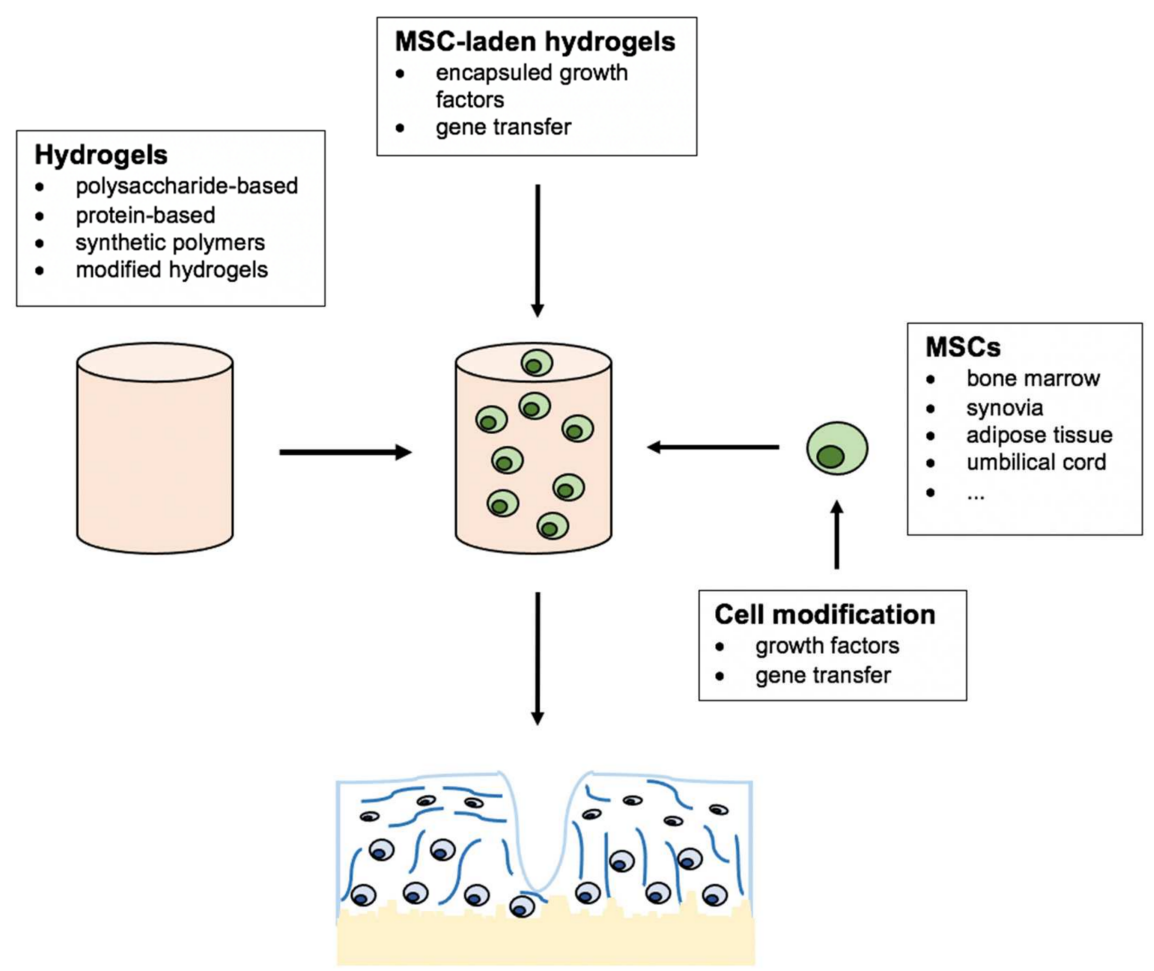

Figure 2. Combinations of hydrogels, mesenchymal stromal cells, and gene transfer, as well as growth factors for cartilage tissue engineering. Image-based on Deng et al., 2020 [14]: Narrative review of the choices of stem cell sources and hydrogels for cartilage tissue engineering.

\subsection{MSCs in Cartilage Tissue Engineering}

The minimal criteria for MSCs, as defined by the International Society for Cell \& Gene Therapy (ISCT), state that MSCs are plastic-adherent cells, presenting a characteristic set of surface antigens that possess adipogenic, osteogenic, and chondrogenic differentiation capacity [71]. MSCs present a promising cell source in the field of TE since they can be isolated in abundance from a wide variety of fetal and adult tissue sources and multiplied by cultivation in vitro. In addition, MSCs possess low immunogenicity and raise few ethical concerns. Although bone marrow-derived MSCs (BMSCs) are still viewed as the gold standard, synovial-derived or adipose tissue-derived MSCs may possess superior chondrogenic differentiation capacity while offering easier access to native tissues [70,72]. While chondrogenesis in MSCs can be stimulated by combination with scaffolds and growth factors, research has revealed that their secretome may also positively influence local tissue and cartilage repair.

\subsection{BMSC-Laden Hydrogels for Cartilage Tissue Engineering}

The most common combination of MSCs and hydrogels used for in vivo cartilage engineering in different animal models are BMSCs combined with HA hydrogels (Table 2) [23,73-81]. Multiple studies used BMSC-laden HA hydrogels for the treatment of osteochondral de- 
fects in animal models. Kim et al. combined injectable HA hydrogels with BMSCs for the treatment of osteochondral defects. They found that the combined use of HA and BMSCs led to a significantly enhanced healing of osteochondral defects, especially when using multiple HA injections [23]. Lee et al. showed similar results when treating osteochondral defects in pigs with superior macroscopic and histological regeneration of hyaline cartilage when combining the use of HA injections and BMSCs in comparison to HA injections or negative controls [75]. Another study examined the effects of BMSC-laden HA hydrogels in the treatment of osteochondral defects of the femorotibial joint in horses. Results showed that microfracture combined with BMSC-laden HA hydrogels led to superior tissue quality in repair tissue compared to the treatment with microfracture and HA hydrogels alone, while no clinically significant differences were observed [73]. Saw et al. found similar results when treating osteochondral defects in goats with superior results in histological hyaline cartilage repair when combining microfracture, HA injections, and BMSCs compared to the use of HA injections and microfracture alone [74]. A clinical trial examined the use of BMSC-laden HA hydrogels for the treatment of osteochondral defects of the knee and found significant improvements in functionality and pain reduction compared to patients treated with microfracture alone (Table 3) [82].

Other researchers combined BMSCs and hydrogels for the treatment of OA in different animal models. Chiang et al. found that BMSCs enhance the positive effects of HA hydrogels when treating OA in rabbit models. The combined use of BMSC and HA hydrogels led to less cartilage loss, fewer surface abrasions, and significant improvements in histological scores and cartilage content compared to using HA hydrogels alone [77]. Other studies confirmed the positive effects on clinical, radiographic, or histological outcomes in animal models of OA when combining BMSCs and HA hydrogels in comparison to negative controls or the use of BMSCs or HA hydrogels alone $[14,79,80]$. Further, DeSando et al. stated that HA supports cell migration to hyaline cartilage when using both BMSCs or bone marrow concentrate, with superior results in the treatment of OA in rabbits when using bone marrow concentrate and HA hydrogels [76]. In contrast, another study showed that the separate use of BMSCs and HA hydrogels may be beneficial for the treatment of $\mathrm{OA}$ in rats [78].

However, BMSCs have also been combined with various other natural or synthetic hydrogels in cartilage TE. Pascual-Garrido et al. treated critical-sized chondral defects in rabbit knees with BMSC-laden photopolymerizable hydrogels and found higher scores after histological cartilage examination in comparison to untreated defects or those only treated with hydrogels [83]. Another study used BMSC-laden AL hydrogels for the treatment of osteochondral defects in the knee of rabbits and found that chondral repair tissue showed more hyaline cartilage-like properties when compared to untreated groups [42]. Choi et al. combined BMSCs treated with resveratrol and gelatin-based hydrogels for the treatment of osteochondral defects in rabbit knees. They found that treatment with these cell-laden hydrogels led to the formation of hyaline cartilage-like repair tissue with vast amounts of collagen type II and increased GAG deposition compared to treatment solely with hydrogels or untreated MSC-laden hydrogels [84]. In addition, Kim et al. examined the therapeutic effects of self-assembled peptide (SAP) hydrogels and BMSCs on OA in rats. The authors found that the combined use of SAP hydrogels and BMSCs led to antiinflammatory effects, decreased levels of apoptosis biomarkers as well as chondroprotective effects on a histological level [85]. 
Table 2. Preclinical studies examining the use of MSC-laden hydrogels for cartilage engineering.

\begin{tabular}{|c|c|c|c|c|c|c|}
\hline Author & Year & Animal; Defect Type & Cell Source & Hydrogel & Study Setup & Results \\
\hline Kim et al. [23] & 2011 & $\begin{array}{ll}\text { - } & \text { Rabbits } \\
& \text { osteochondral defects }\end{array}$ & BMSCs & HA hydrogel & $\begin{array}{ll}- & \text { BMSCs + HA injection } \\
- & \text { BMSCs + 2 HA injections } \\
- & \text { BMSC injection } \\
- & \text { HA injections } \\
& \text { No treatment }\end{array}$ & $\begin{array}{l}\text { - Macroscopic and histological examination } \\
\text { with significantly improved healing of } \\
\text { osteochondral defects compared to } \\
\text { untreated groups } \\
\text { - Superior histological results for } \\
\text { BMSC + 2 HA injections }\end{array}$ \\
\hline Lee et al. [75] & 2007 & $\begin{array}{ll}-\quad & \text { Minipigs } \\
& \text { femoral osteochondral } \\
& \text { defects }\end{array}$ & BMSCs & HA hydrogel & $\begin{array}{ll}- & \text { BMSCs }+ \text { hydrogels } \\
- & \text { Hydrogels } \\
& \text { Saline }\end{array}$ & $\begin{array}{l}\text { - Superior histological and macroscopic } \\
\text { results for cartilage repair when using } \\
\text { BMSC-laden hydrogels compared to } \\
\text { control groups }\end{array}$ \\
\hline McIlwraith et al. [86] & 2011 & $\begin{array}{l}\text { - } \quad \text { Horses } \\
\text { osteochondral defects } \\
\text { femorotibial joint }\end{array}$ & BMSCs & HA hydrogel & $\begin{array}{ll}\text { - } & \text { Microfracture + BMSC-laden } \\
\text { HA hydrogels } \\
\text { - } \\
\text { Microfracture + HA } \\
\text { hydrogels }\end{array}$ & $\begin{array}{l}\text { - No clinical or histological differences } \\
\text { Macroscopic and arthroscopic better tissue } \\
\text { quality and higher aggrecan levels when } \\
\text { adding BMSCs }\end{array}$ \\
\hline Saw et al. [74] & 2009 & $\begin{array}{ll}\text { - } & \text { Goats } \\
\text { osteochondral defects }\end{array}$ & BMSCs & HA hydrogel & $\begin{array}{ll}\text { - } & \text { Microfracture + BMSCs }+3 \\
\text { - } & \text { HA injections } \\
\text { Microfracture + } 3 \mathrm{HA} \\
\text { injections } \\
\text { - } & \text { No treatment }\end{array}$ & $\begin{array}{l}\text { - Successful cartilage repair with superior } \\
\text { results in groups treated with HA } \\
\text { injections and BMSCs }\end{array}$ \\
\hline Mokbel et al. [80] & 2011 & $\begin{array}{ll}\text { - } & \text { Donkeys } \\
\text { - OA }\end{array}$ & BMSCs & HA hydrogels & $\begin{array}{ll}-\quad & \text { BMSCs + hydrogels } \\
& \text { Hydrogels }\end{array}$ & $\begin{array}{l}\text { Successful repair of cartilage defects in } \\
\text { clinical and radiological evaluations in } \\
\text { BMSC + hydrogel group compared with } \\
\text { control groups }\end{array}$ \\
\hline Sato et al. [79] & 2012 & $\begin{array}{ll}- & \text { Pigs } \\
- & \text { OA }\end{array}$ & BMSCs & HA hydrogels & $\begin{array}{ll}- & \text { BMSCs + hydrogels } \\
- & \text { BMSCs } \\
- & \text { Hydrogels } \\
- & \text { Saline }\end{array}$ & $\begin{array}{l}\text { - Histological repair of cartilage defects only } \\
\text { in group treated with the combination of } \\
\text { BMSCs + hydrogels } \\
\text { Elevated collagen type II content in the } \\
\text { group treated with BMSCs + hydrogels }\end{array}$ \\
\hline
\end{tabular}


Table 2. Cont.

\begin{tabular}{|c|c|c|c|c|c|c|}
\hline Author & Year & Animal; Defect Type & Cell Source & Hydrogel & Study Setup & Results \\
\hline Desando et al. [76] & 2018 & $\begin{array}{ll}- & \text { Rabbits } \\
- & \text { OA }\end{array}$ & BMSCs & HA hydrogels & $\begin{array}{ll}- & \text { BMSCs } \\
- & \text { BMSCs }+ \text { hydrogels } \\
- & \text { Bone marrow concentrate } \\
- & \text { Bone marrow concentrate }+ \\
& \text { hydrogels }\end{array}$ & $\begin{array}{l}\text { - } \quad \text { Successful joint repair evident in all groups } \\
\text { HA hydrogels enhance the migration of } \\
\text { seeded cells to cartilage } \\
\text { - } \quad \text { BMSCs favor migration to meniscal tissue } \\
\text { Bone marrow concentrate favors migration } \\
\text { to cartilage }\end{array}$ \\
\hline Suhaeb et al. [78] & 2012 & $\begin{array}{ll}- & \text { Rats } \\
- & \text { OA }\end{array}$ & BMSCs & HA hydrogels & $\begin{array}{ll}- & \text { BMSCs + hydrogels } \\
- & \text { BMSCs } \\
- & \text { Hydrogels }\end{array}$ & $\begin{array}{l}\text { Better counteraction of OA progression } \\
\text { when using Hydrogels and BMSCs alone } \\
\text { compared to the combination of } \\
\text { BMSCs + hydrogels }\end{array}$ \\
\hline Pascual-Garrido et al. [83] & 2019 & $\begin{array}{ll}\text { - } & \text { Rabbits } \\
\text { - } & \text { Critical } \\
\text { - } & \text { in kndral defect } \\
& \end{array}$ & BMSCs & $\begin{array}{l}\text { Novel photopoly-merizable } \\
\text { hydrogel }\end{array}$ & $\begin{array}{ll}- & \text { BMSCs + hydrogels } \\
- & \text { Hydrogels } \\
- & \text { Untreated controls }\end{array}$ & $\begin{array}{ll}\text { - } & \text { Successful chondrogenesis of seeded } \\
\text { BMSCs in vitro } \\
\text { - } \quad \text { Partial cartilage repair in rabbit models } \\
\text { in vivo with } \\
\text { enhanced chondrogenic differentiation in } \\
\text { BMSCs seeded in hydrogels }\end{array}$ \\
\hline Critchley et al. [42] & 2019 & $\begin{array}{ll}\text { - } & \text { Rabbits } \\
\text { Osteochondral defects } \\
\text { knee }\end{array}$ & BMSCs & AL hydrogel & $\begin{array}{ll}- & \text { BMSCs + hydrogels } \\
\text { - } & \text { Untreated controls }\end{array}$ & $\begin{array}{l}\text { Enhanced repair of cartilage defects with } \\
\text { mechanically stable repair tissue in the } \\
\text { group treated with BMSCs + hydrogels }\end{array}$ \\
\hline Kim et al. [85] & 2014 & $\begin{array}{ll}- & \text { Rats } \\
- & \text { OA }\end{array}$ & BMSCs & SAP hydrogels & $\begin{array}{ll}\text { - } & \text { BMSC + hydrogels } \\
\text { - } & \text { BMSCs } \\
\text { - } & \text { Hydrogels } \\
& \text { Negative controls }\end{array}$ & $\begin{array}{l}\text { Anti-inflammatory and chondroprotective } \\
\text { effects, decrease in apoptosis markers in } \\
\text { the group treated with BMSCs + hydrogels } \\
\text { Increased bone mineral density in the } \\
\text { group treated with BMSCs + hydrogels }\end{array}$ \\
\hline
\end{tabular}


Table 3. Clinical studies examining the use of MSC-laden hydrogels for cartilage engineering.

\begin{tabular}{|c|c|c|c|c|c|c|}
\hline Author & Year & Defect Type & $\begin{array}{l}\text { Cell } \\
\text { Source }\end{array}$ & Hydrogel & Study Design & Results \\
\hline Leet et al. [82] & 2012 & Chondral lesion & BMSCs & HA hydrogels & $\begin{array}{ll}\text { - } & \text { BMSCs + } \\
& \text { hydrogel } \\
\text { - } & \text { Microfracture + } \\
& \text { hydrogel }\end{array}$ & $\begin{array}{l}\text { Less-invasive surgery } \\
\text { method for application } \\
\text { of BMSCs + hydrogel } \\
\text { No significant } \\
\text { differences regarding } \\
\text { the functional outcome } \\
\text { and patient satisfaction }\end{array}$ \\
\hline Pipino et al. [87] & 2019 & Osteochondral defect & ADMSCs & $\begin{array}{c}\text { Polyglucosamine/ } \\
\text { glucosamine carbonate } \\
\text { hydrogels }\end{array}$ & $\begin{array}{ll}\text { - } & \text { Microfractures + } \\
& \text { ADMSCs + } \\
\text { - } & \text { hydrogel } \\
\text { Microfracture }\end{array}$ & $\begin{array}{l}\text { High patient } \\
\text { satisfaction following } \\
\text { treatment with } \\
\text { ADMSCs + hydrogels } \\
\text { Enhanced cartilage } \\
\text { repair in the group } \\
\text { treated with } \\
\text { ADMSCs + hydrogels }\end{array}$ \\
\hline
\end{tabular}

ADMSCs: adipose-derived mesenchymal stromal cells; BMSCs: bone marrow-derived MSCs; HA: hyaluronic acid.

\subsection{Hydrogels Combined with Other MSC-Subpopulations}

Different MSC-subpopulations other than BMSCs may offer advantages regarding tissue accessibility, cell abundance, or chondrogenic differentiation capacity [70]. Therefore, multiple studies have focused on the combined use of different MSC-subpopulations with hydrogels (Table 4). Adipose-derived (AD)MSCs represent the second most used MSC subpopulation used in cartilage TE. One study examined the combined effects of ADMSCs and HA hydrogels on OA progression in sheep. Results showed decreased OA progression and increased cartilage regeneration efficacy in comparison to untreated groups or those treated with stromal vascular fraction and HA hydrogels [88]. Feng et al. found similar results combined with anti-inflammatory effects when combining the use of ADMSCs and HA hydrogels for the treatment of OA in sheep models [89]. A recent study by Sevastianov et al. pointed out that ADMSCs seeded in decellularized porcine articular cartilage may produce more cartilage-specific matrix proteins in comparison to MSCs treated in COL hydrogels in vitro [90]. In contrast, ADMSCs seeded in COL hydrogels led to improved cartilage repair in OA in rabbit models in vivo when compared to MSCs seeded in decellularized porcine articular cartilage [90]. A recent clinical trial evaluated the combined effects of ADMSC-laden polyglucosamine/glucosamine carbonate hydrogels and microfracture on osteochondral defects of the knee in forty-six patients. The results showed higher patient satisfaction and superior histological formation of hyaline cartilage in comparison to the control group, which was treated with microfracture alone (Table 3) [87]. 
Table 4. Preclinical studies examining the use of different combinations of MSC-subpopulations and hydrogels for cartilage engineering.

\begin{tabular}{|c|c|c|c|c|c|c|}
\hline Author & Year & Animal; Defect Type & Cell Source & Hydrogel & Study Design & Results \\
\hline Lv et al. [88] & 2018 & $\begin{array}{ll}- & \text { Sheep } \\
\text { - } & \text { OA }\end{array}$ & ADMSCs & HA hydrogel & $\begin{array}{ll}- & \text { ADMSCs (high dose) + hydrogel } \\
- & \text { ADMSCs (low dose) + hydrogel } \\
- & \text { Stromal vascular fraction } \\
- & \text { Hydrogel } \\
& \text { Saline }\end{array}$ & $\begin{array}{l}\text { - Superior results in the delay of OA } \\
\text { progression and cartilage repair } \\
\text { when using ADMSCs and hydrogels }\end{array}$ \\
\hline Feng et al. [89] & 2018 & $\begin{array}{ll}- & \text { Sheep } \\
- & \text { OA }\end{array}$ & ADMSCs & HA hydrogels & $\begin{array}{ll} & \text { ADMSCs (high dose) + hydrogel } \\
- & \text { ADMSCs (low dose) + hydrogel } \\
- & \text { Hydrogel } \\
- & \text { Saline }\end{array}$ & $\begin{array}{l}\text { - Anti-inflammatory effects and repair } \\
\text { tissue with typical articular cartilage } \\
\text { features when using ADMSCs } \\
\text { and hydrogels }\end{array}$ \\
\hline Jia et al. [91] & 2019 & $\begin{array}{ll}\text { - } & \text { Rabbits } \\
\text { Osteochondral defects } \\
\text { of the knee }\end{array}$ & $\begin{array}{l}\text { Synovial fluid-derived } \\
\text { MSCs }\end{array}$ & $\mathrm{CH}$ hydrogels & $\begin{array}{ll}- & \text { MSCs + hydrogel } \\
- & \text { Hydrogel } \\
- & \text { Untreated controls }\end{array}$ & $\begin{array}{l}\text { Improved macroscopic appearance } \\
\text { and histological results in the group } \\
\text { treated with MSCs + hydrogels }\end{array}$ \\
\hline Li et al., [93] & 2018 & $\begin{array}{l}\text { - } \quad \text { Rats } \\
\text { - } \quad \text { of theochondral defect } \\
\text { of thee }\end{array}$ & $\begin{array}{l}\text { Arthroscopic flushing } \\
\text { fluid-derived MSCs }\end{array}$ & Polypegda/HA hydrogels & $\begin{array}{ll}- & \text { MSCs + hydrogel } \\
- & \text { Hydrogel } \\
\text { - } & \text { Untreated controls }\end{array}$ & - $\quad$ Significantly improved \\
\hline
\end{tabular}

ADMSCs: adipose-derived mesenchymal stromal cells; $\mathrm{CH}$ : chitosan; HA: hyaluronic acid; OA: osteoarthritis. 
Jia et al. seeded synovial fluid-derived MSCs in injectable $\mathrm{CH}$ hydrogels for the treatment of femoral full-thickness cartilage defects in rabbits [91]. Results revealed that MSC-laden hydrogels led to superior histological cartilage repair when compared to only hydrogels or controls. Wu et al. found that the combined use of HA hydrogels and human umbilical cord-derived MSCs may be an effective treatment for OA in minipig models [92] $\mathrm{Li}$ et al. showed that the therapeutic use of arthroscopic flushing fluid-derived MSCs encapsulated in a polyPEGDA/HA hydrogel led to the significant repair of full-thickness cartilage defects as well as macroscopic smooth cartilage in rats [93].

2.10. Gene Transfer and Growth Factors Combined with Hydrogels for Cartilage Tissue Engineering

Hypertrophic and osteogenic de-differentiation remains a major problem regarding the repair of chondral and osteochondral defects using MSCs and may result in the formation of hypertrophic cartilage tissue or osteophytes in vivo [4]. Although the combination of MSCs with specific natural, synthetic, or modified hydrogels has shown promising results for the repair of cartilage defects both in vitro and in vivo, the combination with specific growth factors may further enhance and guide the differentiation of encapsulated MSCs (Table 5) $[14,94,95]$. 
Table 5. Studies examining the combined use of MSCs, growth factors/gene transfer, and hydrogels for cartilage engineering.

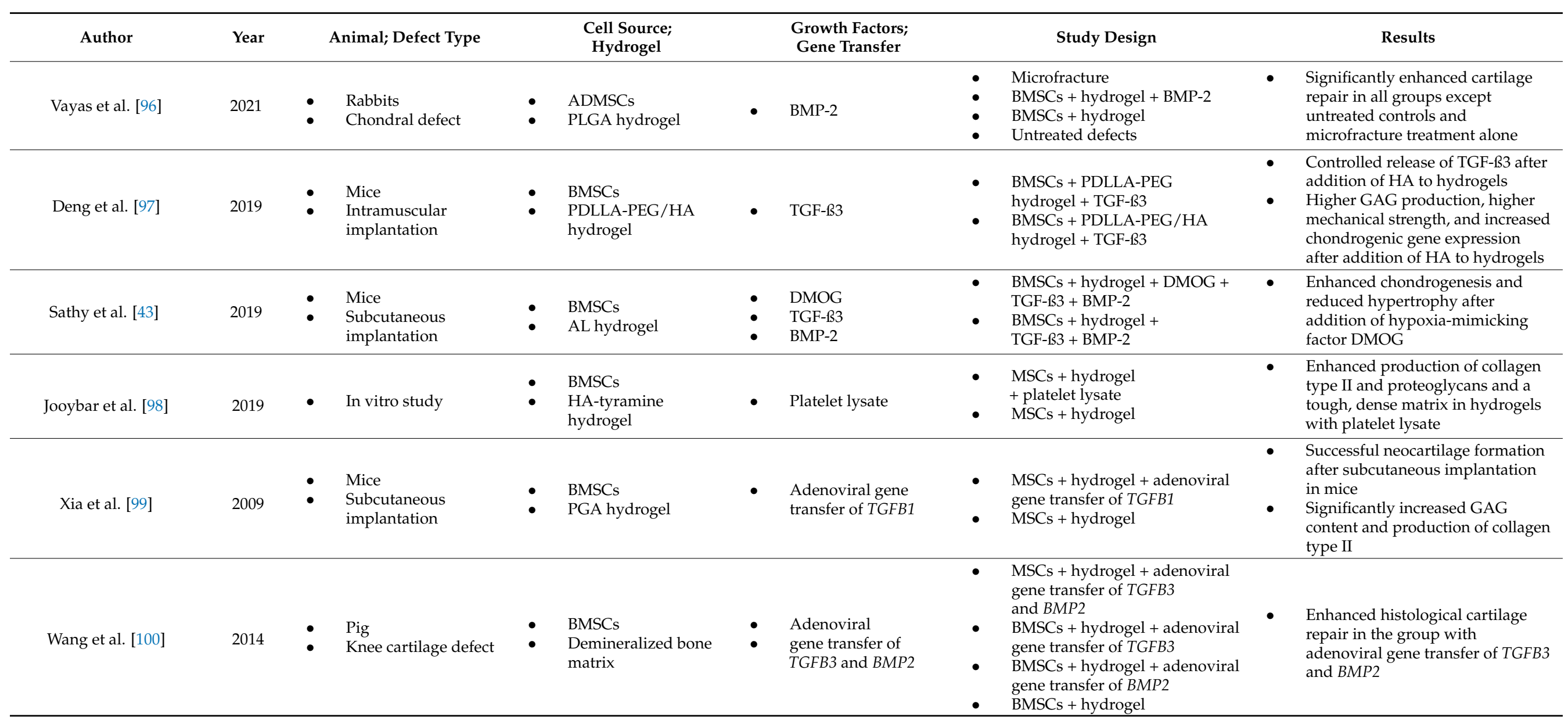


Table 5. Cont.

\begin{tabular}{|c|c|c|c|c|c|c|}
\hline Author & Year & Animal; Defect Type & $\begin{array}{l}\text { Cell Source; } \\
\text { Hydrogel }\end{array}$ & $\begin{array}{l}\text { Growth Factors; } \\
\text { Gene Transfer }\end{array}$ & Study Design & Results \\
\hline Cao et al. [101] & 2011 & $\begin{array}{ll}- & \text { Rabbit } \\
- & \text { Cartilage defect }\end{array}$ & $\begin{array}{ll}- & \text { BMSCs } \\
- & \text { PGA hydrogel }\end{array}$ & $\begin{array}{ll}- & \text { Adenoviral gene } \\
\text { transfer of SOX9 }\end{array}$ & $\begin{array}{ll}\text { - } & \text { BMSCs + hydrogel + adenoviral } \\
\text { gene transfer of SOX9 } \\
\text { - }\end{array}$ & $\begin{array}{l}\text { Repair of full-thickness cartilage } \\
\text { defects in rabbit models } \\
\text { Enhanced repair, more } \\
\text { cartilage-like tissue, and } \\
\text { cartilage-like ECM in the group } \\
\text { treated with adenoviral gene } \\
\text { transfer of SOX9 }\end{array}$ \\
\hline Weißenberger et al. [19] & 2020 & - $\quad$ In vitro study & $\begin{array}{ll}\bullet & \text { BMSCs } \\
- & \text { COL type I hydrogel }\end{array}$ & $\begin{array}{l}\text { Adenoviral gene } \\
\text { transfer of SOX9, } \\
T G F B 1 \text {, or BMP2 }\end{array}$ & $\begin{array}{ll}\text { - } & \text { BMSCs + hydrogel + adenoviral } \\
\text { gene transfer of SOX9 } \\
\text { - } \quad \text { BMSCs + hydrogel + adenoviral } \\
\text { gene transfer of TGFB1 } \\
\text { - } \quad \text { BMSCs + hydrogel + adenoviral } \\
\text { gene transfer of BMP2 } \\
\text { - } \quad \text { BMSCs + hydrogel } \\
\end{array}$ & $\begin{array}{l}\text { Enhanced chondrogenic } \\
\text { differentiation and decreased } \\
\text { hypertrophic de-differentiation in } \\
\text { BMSC-laden hydrogels treated } \\
\text { with adenoviral gene transfer } \\
\text { of SOX9 }\end{array}$ \\
\hline Venkatesan et al. [102] & 2018 & - In vitro study & $\begin{array}{ll}- & \text { BMSCs } \\
- & \text { Fibrin/ } \\
\text { - } & \text { polyurethane } \\
& \text { hydrogel }\end{array}$ & $\begin{array}{l}\text { Recombinant } \\
\text { adeno-associated gene } \\
\text { transfer of SOX9 }\end{array}$ & $\begin{array}{ll}\text { - } & \text { BMSCs + hydrogel + } \\
\text { recombinant adeno-associated } \\
\text { gene transfer of SOX9 } \\
\text { - } \quad \text { BMSCs + hydrogel }\end{array}$ & $\begin{array}{l}\text { Enhanced chondrogenesis in } \\
\text { cultures treated with recombinant } \\
\text { adeno-associated gene transfer } \\
\text { of SOX9 }\end{array}$ \\
\hline Lee et al. [104] & 2012 & $\begin{array}{ll}\text { - } & \text { Rat } \\
\text { - Chondral defects }\end{array}$ & $\begin{array}{ll}- & \text { ADMSCs } \\
- & \text { Fibrin hydrogel }\end{array}$ & $\begin{array}{ll}- & \text { Retroviral gene } \\
\text { transfer of SOX5, } \\
\text { SOX6, and SOX9 }\end{array}$ & $\begin{array}{ll}\text { - } & \text { ADMSCs + hydrogel + } \\
\text { recombinant adeno-associated } \\
\text { gene transfer } \\
\text { Retroviral gene transfer of SOX5, } \\
\text { SOX6, SOX9, or of the SOX-trio } \\
\text { - } \quad \text { ADMSCs + hydrogel + treatment } \\
\text { with TGF-B2 and BMP-7 }\end{array}$ & $\begin{array}{l}\text { - Successful repair of full-thickness } \\
\text { cartilage defects in vivo in } \\
\text { all groups } \\
\text { Significantly enhanced expression } \\
\text { of chondrogenic marker genes, } \\
\text { production of collagen type II, and } \\
\text { GAG content in the group } \\
\text { transduced with the SOX-trio }\end{array}$ \\
\hline
\end{tabular}

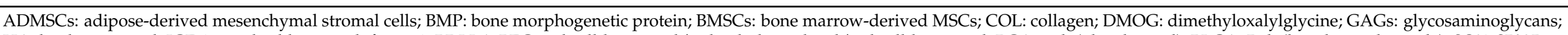

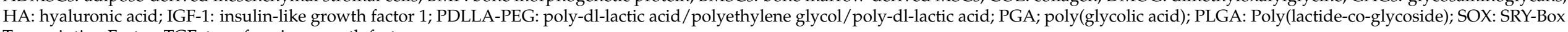
Transcription Factor; TGF: transforming growth factor. 
Different growth factors from the transforming growth factor (TGF)- $§$ superfamily have been used to enhance chondrogenic differentiation of MSCs encapsulated in hydrogels. PLGA hydrogels were modified with bone morphogenetic protein (BMP)-2 to provide better support for encapsulated BMSCs [96]. Synthetic hydrogels modified with HA and preloaded with TGF-B3 led to enhanced chondrogenesis in seeded BMSCs and showed increased mechanical strength [97]. Further hypoxia mimicking AL hydrogels loaded with BMP-2, TGF-B3 reduced hypertrophic de-differentiation in seeded BMSCs [43]. Platelet lysate contains various growth factors able to enhance the formation of a hyaline cartilagelike ECM when incorporated in MSC-laden hydrogels [98].

Further, we and others showed that gene transfer of different members of the TGF$B$ superfamily led to enhanced chondrogenesis of BMSCs seeded in hydrogels in vitro and in vivo [19,99-101,103-106]. Xia et al. found that adenoviral gene transfer of TGF-B1 (encoded by TGFB1) to BMSCs encapsulated in PGA hydrogels led to enhanced chondrogenesis in vivo [99]. Wang et al. showed that adenoviral gene transfer of TGF-B3 (encoded by TGFB3) and BMP-2 (encoded by BMP2) to BMSCs encapsulated in demineralized bone matrix led to enhanced cartilage repair in pig models [100]. Different studies showed that the gene transfer of SRY-Box Transcription Factor (SOX)-9 (encoded by SOX9) may further enhance chondrogenesis in BMSC seeded in natural or synthetic hydrogels while limiting hypertrophic de-differentiation $[19,102,107]$. Cao et al. showed that adenoviral gene transfer of SOX9 to BMSCs seeded in PGA hydrogels led to enhanced cartilage repair in rabbit models in comparison to conventional BMSC-laden PGA hydrogels [101]. Further, gene transfer of different members of the TGF- $B$ superfamily to ADMSCs seeded in natural or synthetic hydrogels led to successful cartilage repair and delayed progression of $\mathrm{OA}$ in rat models $[103,104]$.

\section{Discussion}

Hyaline cartilage is a highly specialized and complex tissue and with limited regenerative potential. Although cell-based methods have emerged as a successful treatment option for OA and cartilage defects major obstacles, such as loss of transplanted cells, adequate chondrogenic differentiation, and phenotype maintenance, as well as chondrogenic hypertrophy and osteogenic de-differentiation or integration difficulties, remain $[4,12]$. To further optimize TE approaches for cartilage repair, research has focused on different combinations of scaffolds, MSC-subpopulations, and growth factors. This review focused on the use of MSC-laden hydrogels and possible modifications using growth factors or gene transfer for use in cartilage engineering.

Different natural, synthetic, and modified hydrogels possess specific advantages and disadvantages, considering their clinical use. However, the modification of hydrogels offers to combine advantages of both natural and synthetic polymers to optimize biocompatibility, mechanical structure, biodegradability, and induction of chondrogenesis in seeded cells $[5,14]$. Further, different natural and synthetic hydrogels have been approved for clinical use, making them highly attractive scaffolds for cell-based cartilage engineering [12,26].

Although autologous chondrocytes are used in many current cell-based cartilage repair methods, such as autologous chondrocyte implantation (ACI), MSCs can be isolated in great numbers from various easily accessible tissues. In addition, MSCs possess greater proliferation potential while offering great chondrogenic differentiation capacity $[69,108]$. When choosing the right MSC-subpopulations for cartilage TE, tissue accessibility, cell abundance, and chondrogenic differentiation capacity have to be considered. Natural polymers in hydrogels have been shown to influence cell functionality in both chondrocytes and MSCs promoting chondrogenesis and the formation of hyaline cartilage-like ECM as well as limiting hypertrophic de-differentiation, although these effects are limited by biodegrading of biomaterials $[14,28]$.

The success of cell-laden hydrogels in cartilage TE depends on the maintenance of cell viability, the synthesis of ECM components, and tissue integration [17]. The addition 
of specific growth factors or gene transfer to encapsulated MSCs may further influence cell functionality and suitability for cartilage TE as well as all of the variables mentioned above. As pointed out earlier, numerous growth factors from the TGF- $\beta$ superfamily have been shown to promote chondrogenesis in seeded MSCs in hydrogels in vitro and in vivo. Further gene transfer of SOX9 has been shown to promote not only chondrogenic differentiation in seeded MSCs but also limit hypertrophic differentiation in MSC-laden hydrogels in vitro $[17,19]$. The combination with bioactive substances and MSCs may help to overcome the hurdle of rapid degradation in natural hydrogels, which often takes place faster than hydrogels can be replaced by de novo ECM [17].

To determine the ideal composition of MSC-subpopulations, loaded growth factors, or gene transfer and hydrogels, further research and clinical trials are necessary, especially regarding the use of more complex hydrogels modified with specific growth factors or gene transfer. In this context, bioprinted biphasic or triphasic biomaterials mimicking the multizonal construction of the osteochondral interface have emerged as a promising alternative $[109,110]$. These scaffolds offer an osseous and a chondral layer as well as a potential third layer mimicking calcified cartilage [110]. Although preclinical and clinical studies show encouraging results, the combination of more phasic biomaterials with specific MSC-subpopulations and growth factors to recreate the zonal structure of native hyaline cartilage remains challenging, and until now, no effective strategy to reliably direct zonal differentiation in seeded cells has been developed [110,111].

\section{Conclusions}

MSC-laden hydrogels offer a promising approach for the treatment of cartilage defects. Currently, the combination of natural hydrogels with BMSCs offers the most clinical experience. However, other MSC-subpopulations may provide various advantages, including better accessibility of the native tissue source as well as the improved proliferative and chondrogenic potential of cells. In addition, modified hydrogels may improve chondrogenic differentiation, maintain chondrogenic phenotype and decrease hypertrophic differentiation in seeded cells while providing optimal biocompatibility, stability, and biodegradability. Bioprinted biphasic scaffolds are a promising option for the reconstruction of the functional osteochondral unit.

\section{Material and Methods}

\subsection{Methods Used for Literature Research}

The research for this narrative review was performed with the PubMed database using the following search strings: "stem cells" OR "mesenchymal stromal cells" OR "MSCs" AND "hydrogel" AND "gene transfer" OR "growth factors" AND "cartilage repair" OR "cartilage defects". We selected papers published in English that were released up to August 2021. We included preclinical and clinical studies examining the effects of MSC-laden hydrogels alone or in combination with chondrogenic growth factors for cartilage tissue engineering. We also included in vitro and preclinical studies examining the effects of MSC-laden hydrogels in combination with gene transfer for the regeneration of hyaline cartilage.

\subsection{Results of Literature Research}

The results of our literature research are pictured in Figure 3. The described search string led to 357 initial articles. After excluding duplicates, 200 papers remained. Following this procedure, we performed a manual review based on displayed study titles and abstracts which was performed by three independent reviewers. We found that 32 articles represented reviews or presentations, and 45 studies did not cover the use of cell and cell-laden hydrogels for the treatment of cartilage defects. After a full review, out of the consisting articles, 30 papers did not relate to MSCs resulting in a total of 93 studies after screening. 


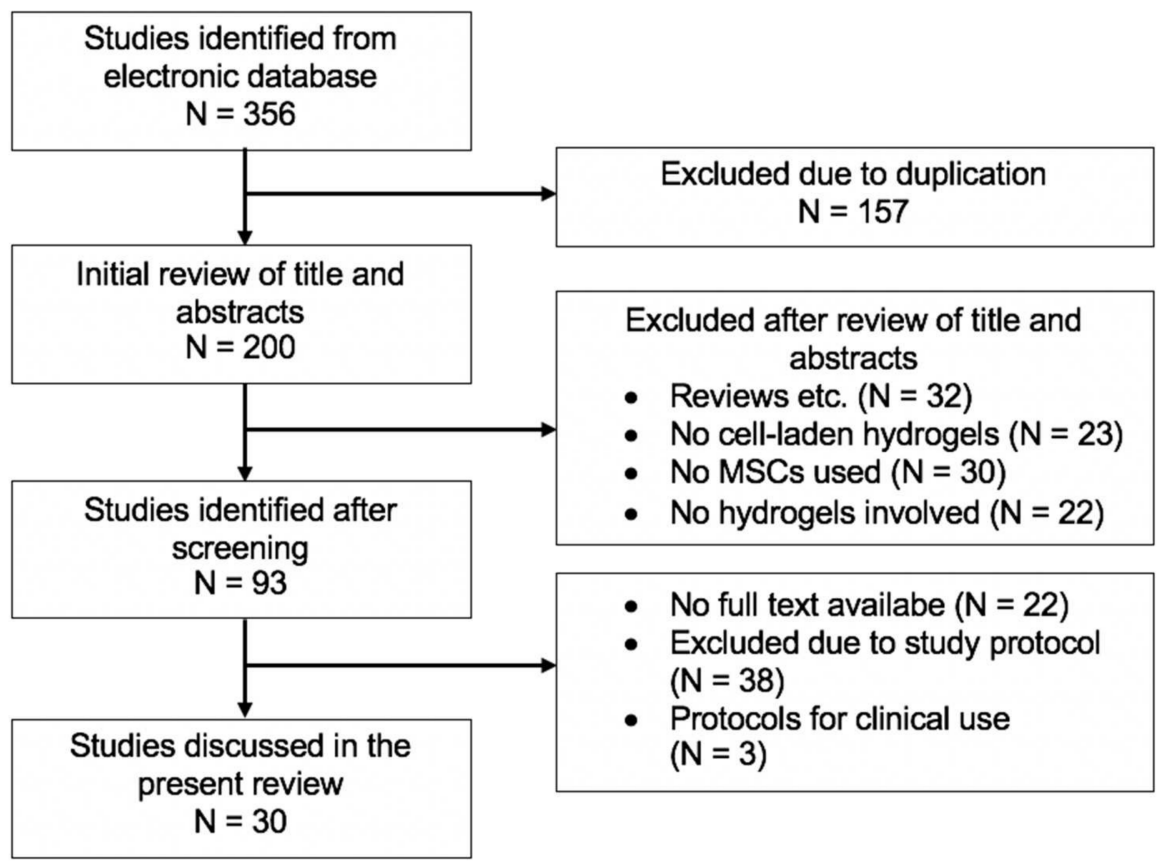

Figure 3. Flowchart for literature research in the present review.

After excluding 22 articles with no availability of full-text, 3 studies with no available study protocol, and 38 studies that did not present a fitting study protocol after review of the abstract or materials and methods section, we included 27 preclinical studies and 3 clinical studies in this present narrative review discussing the engineering of cartilage defects with MSC-laden hydrogels. We divided the search results into preclinical research examining the effects of MSC-laden hydrogels, MSC-laden hydrogels in combination with growth factors, and MSC-laden hydrogels in combination with gene transfer, as well as clinical studies examining the effect of MSC-laden hydrogels on cartilage repair.

Author Contributions: Conceptualization, M.W. (Mike Wagenbrenner) and M.W. (Manuel Weissenberger).; Methodology, M.W. (Mike Wagenbrenner) and M.W. (Manuel Weissenberger); Software, M.W. (Mike Wagenbrenner); Validation, M.W. (Mike Wagenbrenner) and M.W. (Manuel Weissenberger), B.M.H., S.M.-W., M.R.; Formal Analysis, M.W. (Mike Wagenbrenner) and M.W. (Manuel Weissenberger); Investigation, M.W. (Mike Wagenbrenner); Resources, M.W. (Mike Wagenbrenner) and M.W. (Manuel Weissenberger); Data Curation, M.W. (Mike Wagenbrenner) and M.W. (Manuel Weissenberger), B.M.H. and S.M.-W. and M.R.; Writing-Original Draft Preparation, M.W. (Mike Wagenbrenner) and M.W. (Manuel Weissenberger); Writing-Review \& Editing, M.W. (Mike Wagenbrenner) and M.W. (Manuel Weissenberger); Visualization, M.W. (Mike Wagenbrenner); Supervision, M.W. (Mike Wagenbrenner) and M.W. (Manuel Weissenberger and B.M.H. and M.R.; Project Administration, M.W. (Mike Wagenbrenner) and M.W. (Manuel Weissenberger); M.W. (Mike Wagenbrenner) and M.W. (Manuel Weissenberger) performed the screening of electronic databases. M.W. (Mike Wagenbrenner) and M.W. (Manuel Weissenberger) wrote the manuscript and designed the tables and figures. All authors contributed to the study design, data analysis, interpretation of data, and drafting and revision of the manuscript. All authors have read and agreed to the published version of the manuscript.

Funding: No funding or financial support were involved in this review.

Informed Consent Statement: Not applicable.

Data Availability Statement: The datasets used and analyzed during the current study are available from the corresponding author on reasonable request.

Conflicts of Interest: The authors declare they have no competing interests. 


\begin{abstract}
Abbreviations
ADMSCs: adipose-derived mesenchymal stromal cells; AG: agarose; AL: alginate; BMP: bone morphogenetic protein; BMSCs: bone marrow-derived MSCs; $\mathrm{CH}$ : chitosan; COL: collagen; DMOG: dimethyloxalylglycine; ECM: extracellular matrix; EL: elastin; ESCs: embryonic stem cells; GAGs: glycosaminoglycans; GEL: gelatin; gelMA: gelatin-methacryloyl; HA: hyaluronic acid; IGF-1: insulinlike growth factor 1; iPSCs: induced pluripotent stem cells; ISCT: International society for Cell \& Gene Therapy; MSCs: Mesenchymal stromal cells; OA: Osteoarthritis; PDLLA-PEG: poly-d,l-lactic acid/polyethylene glycol/poly-d,l-lactic acid; PEG: polyethylene glycol; PEGDA: PEG-diacrylate; PGA; poly(glycolic acid); PLA: polylactic acid; PLGA: Poly(lactide-co-glycolide); PVA: polyvinyl alcohol; PVCL: Poly(N-vinylcaprolactam); SAP: self-assembled peptide; SOX: SRY-Box Transcription Factor; TE: Tissue Engineering; TGF: transforming growth factor.
\end{abstract}

\title{
References
}

1. OECD. Health at a Glance 2019 OECD Indicators: OECD Indicators; OECD Publishing: Paris, France, 2019. [CrossRef]

2. Pilz, V.; Hanstein, T.; Skripitz, R. Projections of primary hip arthroplasty in Germany until 2040. Acta Orthop. 2018, 89, 308-313. [CrossRef]

3. Klug, A.; Gramlich, Y.; Rudert, M.; Drees, P.; Hoffmann, R.; Weißenberger, M.; Kutzner, K.P. The projected volume of primary and revision total knee arthroplasty will place an immense burden on future health care systems over the next 30 years. Knee Surg. Sports Traumatol. Arthrosc. J. ESSKA 2020, 29, 3287-3298. [CrossRef]

4. Steinert, A.F.; Ghivizzani, S.C.; Rethwilm, A.; Tuan, R.S.; Evans, C.H.; Noth, U. Major biological obstacles for persistent cell-based regeneration of articular cartilage. Arthritis Res. 2007, 9, 213. [CrossRef]

5. Huang, K.; Li, Q.; Li, Y.; Yao, Z.; Luo, D.; Rao, P.; Xiao, J. Cartilage Tissue Regeneration: The Roles of Cells, Stimulating Factors and Scaffolds. Curr. Stem Cell Res. Ther. 2018, 13, 547-567. [CrossRef] [PubMed]

6. Dzobo, K.; Thomford, N.E.; Senthebane, D.A.; Shipanga, H.; Rowe, A.; Dandara, C.; Pillay, M.; Motaung, K. Advances in Regenerative Medicine and Tissue Engineering: Innovation and Transformation of Medicine. Stem Cells Int. 2018, 2018, 2495848. [CrossRef]

7. Mancuso, P.; Raman, S.; Glynn, A.; Barry, F.; Murphy, J.M. Mesenchymal Stem Cell Therapy for Osteoarthritis: The Critical Role of the Cell Secretome. Front. Bioeng. Biotechnol. 2019, 7, 9. [CrossRef] [PubMed]

8. Ahmed, T.A.; Hincke, M.T. Mesenchymal stem cell-based tissue engineering strategies for repair of articular cartilage. Histol. Histopathol. 2014, 29, 669-689. [CrossRef]

9. Pham, P.V. Bone and Cartilage Regeneration, 1st ed.; Springer: Cham, Switzerland, 2016; Volume 22.

10. Berebichez-Fridman, R.; Gomez-Garcia, R.; Granados-Montiel, J.; Berebichez-Fastlicht, E.; Olivos-Meza, A.; Granados, J.; Velasquillo, C.; Ibarra, C. The Holy Grail of Orthopedic Surgery: Mesenchymal Stem Cells-Their Current Uses and Potential Applications. Stem Cells Int. 2017, 2017, 2638305. [CrossRef]

11. Caplan, A.I. Mesenchymal Stem Cells: Time to Change the Name! Stem Cells Transl. Med. 2017, 6, 1445-1451. [CrossRef] [PubMed]

12. Lee, W.Y.; Wang, B. Cartilage repair by mesenchymal stem cells: Clinical trial update and perspectives. J. Orthop. Transl. 2017, 9, 76-88. [CrossRef]

13. Hosseini, S.; Eslaminejad, M.B. Mesenchymal Stem Cells: An Optimistic Cell Source in Tissue Engineering for Bone Regeneration. In Bone and Cartilage Regeneration; Pham, P.V., Ed.; Springer International Publishing: Cham, Switzerland, 2016; pp. $205-243$.

14. Deng, Z.; Jin, J.; Wang, S.; Qi, F.; Chen, X.; Liu, C.; Li, Y.; Ma, Y.; Lyu, F.; Zheng, Q. Narrative review of the choices of stem cell sources and hydrogels for cartilage tissue engineering. Ann. Transl. Med. 2020, 8, 1598. [CrossRef]

15. Wei, W.; Ma, Y.; Yao, X.; Zhou, W.; Wang, X.; Li, C.; Lin, J.; He, Q.; Leptihn, S.; Ouyang, H. Advanced hydrogels for the repair of cartilage defects and regeneration. Bioact. Mater. 2021, 6, 998-1011. [CrossRef] [PubMed]

16. Gugjoo, M.B.; Sharma, G.T.; Aithal, H.P.; Kinjavdekar, P. Cartilage tissue engineering: Role of mesenchymal stem cells along with growth factors \& scaffolds. Indian J. Med. Res. 2016, 144, 339-347. [CrossRef]

17. Chuah, Y.J.; Peck, Y.; Lau, J.E.; Hee, H.T.; Wang, D.A. Hydrogel based cartilaginous tissue regeneration: Recent insights and technologies. Biomater. Sci. 2017, 5, 613-631. [CrossRef] [PubMed]

18. Spiller, K.L.; Maher, S.A.; Lowman, A.M. Hydrogels for the repair of articular cartilage defects. Tissue Eng. Part B Rev. 2011, 17, 281-299. [CrossRef]

19. Weißenberger, M.; Weißenberger, M.H.; Wagenbrenner, M.; Heinz, T.; Reboredo, J.; Holzapfel, B.M.; Rudert, M.; Groll, J.; Evans, C.H.; Steinert, A.F. Different types of cartilage neotissue fabricated from collagen hydrogels and mesenchymal stromal cells via SOX9, TGFB1 or BMP2 gene transfer. PLoS ONE 2020, 15, e0237479. [CrossRef]

20. Sánchez-Téllez, D.A.; Téllez-Jurado, L.; Rodríguez-Lorenzo, L.M. Hydrogels for Cartilage Regeneration, from Polysaccharides to Hybrids. Polymers 2017, 9, 671. [CrossRef] [PubMed]

21. Peretti, G.M.; Xu, J.W.; Bonassar, L.J.; Kirchhoff, C.H.; Yaremchuk, M.J.; Randolph, M.A. Review of injectable cartilage engineering using fibrin gel in mice and swine models. Tissue Eng. 2006, 12, 1151-1168. [CrossRef] [PubMed] 
22. Sharma, B.; Fermanian, S.; Gibson, M.; Unterman, S.; Herzka, D.A.; Cascio, B.; Coburn, J.; Hui, A.Y.; Marcus, N.; Gold, G.E.; et al. Human cartilage repair with a photoreactive adhesive-hydrogel composite. Sci. Transl. Med. 2013, 5, 167ra1666. [CrossRef] [PubMed]

23. Kim, I.L.; Mauck, R.L.; Burdick, J.A. Hydrogel design for cartilage tissue engineering: A case study with hyaluronic acid. Biomaterials 2011, 32, 8771-8782. [CrossRef]

24. Schneider, U.; Rackwitz, L.; Andereya, S.; Siebenlist, S.; Fensky, F.; Reichert, J.; Loer, I.; Barthel, T.; Rudert, M.; Noth, U. A prospective multicenter study on the outcome of type I collagen hydrogel-based autologous chondrocyte implantation (CaReS) for the repair of articular cartilage defects in the knee. Am. J. Sports Med. 2011, 39, 2558-2565. [CrossRef] [PubMed]

25. Zhang, X.; Zhang, W.; Yang, M. Application of Hydrogels in Cartilage Tissue Engineering. Curr. Stem Cell Res. Ther. 2018, 13, 497-516. [CrossRef]

26. Catoira, M.C.; Fusaro, L.; Di Francesco, D.; Ramella, M.; Boccafoschi, F. Overview of natural hydrogels for regenerative medicine applications. J. Mater. Sci. Mater. Med. 2019, 30, 115. [CrossRef] [PubMed]

27. Vega, S.L.; Kwon, M.Y.; Burdick, J.A. Recent advances in hydrogels for cartilage tissue engineering. Eur. Cells Mater. 2017, 33, 59-75. [CrossRef] [PubMed]

28. Li, L.; Yu, F.; Zheng, L.; Wang, R.; Yan, W.; Wang, Z.; Xu, J.; Wu, J.; Shi, D.; Zhu, L.; et al. Natural hydrogels for cartilage regeneration: Modification, preparation and application. J. Orthop. Transl. 2019, 17, 26-41. [CrossRef] [PubMed]

29. Fraser, J.R.; Laurent, T.C.; Laurent, U.B. Hyaluronan: Its nature, distribution, functions and turnover. J. Intern. Med. 1997, 242, 27-33. [CrossRef] [PubMed]

30. Liu, M.; Zeng, X.; Ma, C.; Yi, H.; Ali, Z.; Mou, X.; Li, S.; Deng, Y.; He, N. Injectable hydrogels for cartilage and bone tissue engineering. Bone Res. 2017, 5, 17014. [CrossRef]

31. Kang, M.L.; Jeong, S.Y.; Im, G.I. Hyaluronic Acid Hydrogel Functionalized with Self-Assembled Micelles of Amphiphilic PEGylated Kartogenin for the Treatment of Osteoarthritis. Tissue Eng. Part A 2017, 23, 630-639. [CrossRef]

32. Barbucci, R.; Lamponi, S.; Borzacchiello, A.; Ambrosio, L.; Fini, M.; Torricelli, P.; Giardino, R. Hyaluronic acid hydrogel in the treatment of osteoarthritis. Biomaterials 2002, 23, 4503-4513. [CrossRef]

33. Toh, W.S.; Lee, E.H.; Guo, X.M.; Chan, J.K.; Yeow, C.H.; Choo, A.B.; Cao, T. Cartilage repair using hyaluronan hydrogelencapsulated human embryonic stem cell-derived chondrogenic cells. Biomaterials 2010, 31, 6968-6980. [CrossRef]

34. Bian, L.; Zhai, D.Y.; Tous, E.; Rai, R.; Mauck, R.L.; Burdick, J.A. Enhanced MSC chondrogenesis following delivery of TGF- $\beta 3$ from alginate microspheres within hyaluronic acid hydrogels in vitro and in vivo. Biomaterials 2011, 32, 6425-6434. [CrossRef] [PubMed]

35. Vázquez, C.P.; Boudou, T.; Dulong, V.; Nicolas, C.; Picart, C.; Glinel, K. Variation of polyelectrolyte film stiffness by photo-crosslinking: A new way to control cell adhesion. Langmuir 2009, 25, 3556-3563. [CrossRef] [PubMed]

36. Pravata, L.; Braud, C.; Boustta, M.; El Ghzaoui, A.; Tømmeraas, K.; Guillaumie, F.; Schwach-Abdellaoui, K.; Vert, M. New amphiphilic lactic acid oligomer-hyaluronan conjugates: Synthesis and physicochemical characterization. Biomacromolecules 2008, 9, 340-348. [CrossRef]

37. Zhu, D.; Wang, H.; Trinh, P.; Heilshorn, S.C.; Yang, F. Elastin-like protein-hyaluronic acid (ELP-HA) hydrogels with decoupled mechanical and biochemical cues for cartilage regeneration. Biomaterials 2017, 127, 132-140. [CrossRef]

38. Feng, Q.; Lin, S.; Zhang, K.; Dong, C.; Wu, T.; Huang, H.; Yan, X.; Zhang, L.; Li, G.; Bian, L. Sulfated hyaluronic acid hydrogels with retarded degradation and enhanced growth factor retention promote hMSC chondrogenesis and articular cartilage integrity with reduced hypertrophy. Acta Biomater. 2017, 53, 329-342. [CrossRef]

39. Ivanovska, J.; Zehnder, T.; Lennert, P.; Sarker, B.; Boccaccini, A.R.; Hartmann, A.; Schneider-Stock, R.; Detsch, R. Biofabrication of 3D Alginate-Based Hydrogel for Cancer Research: Comparison of Cell Spreading, Viability, and Adhesion Characteristics of Colorectal HCT116 Tumor Cells. Tissue Eng. Part C Methods 2016, 22, 708-715. [CrossRef] [PubMed]

40. Brandl, F.; Sommer, F.; Goepferich, A. Rational design of hydrogels for tissue engineering: Impact of physical factors on cell behavior. Biomaterials 2007, 28, 134-146. [CrossRef] [PubMed]

41. Hashimoto, T.; Suzuki, Y.; Tanihara, M.; Kakimaru, Y.; Suzuki, K. Development of alginate wound dressings linked with hybrid peptides derived from laminin and elastin. Biomaterials 2004, 25, 1407-1414. [CrossRef]

42. Critchley, S.; Cunniffe, G.; O’Reilly, A.; Diaz-Payno, P.; Schipani, R.; McAlinden, A.; Withers, D.; Shin, J.; Alsberg, E.; Kelly, D.J. Regeneration of Osteochondral Defects Using Developmentally Inspired Cartilaginous Templates. Tissue Eng. Part A 2019, 25, 159-171. [CrossRef] [PubMed]

43. Sathy, B.N.; Daly, A.; Gonzalez-Fernandez, T.; Olvera, D.; Cunniffe, G.; McCarthy, H.O.; Dunne, N.; Jeon, O.; Alsberg, E.; Donahue, T.L.H.; et al. Hypoxia mimicking hydrogels to regulate the fate of transplanted stem cells. Acta Biomater. 2019, 88, 314-324. [CrossRef]

44. Müller, M.; Öztürk, E.; Arlov, Ø.; Gatenholm, P.; Zenobi-Wong, M. Alginate Sulfate-Nanocellulose Bioinks for Cartilage Bioprinting Applications. Ann. Biomed. Eng. 2017, 45, 210-223. [CrossRef] [PubMed]

45. Zarrintaj, P.; Manouchehri, S.; Ahmadi, Z.; Saeb, M.R.; Urbanska, A.M.; Kaplan, D.L.; Mozafari, M. Agarose-based biomaterials for tissue engineering. Carbohydr. Polym. 2018, 187, 66-84. [CrossRef] [PubMed]

46. Cigan, A.D.; Roach, B.L.; Nims, R.J.; Tan, A.R.; Albro, M.B.; Stoker, A.M.; Cook, J.L.; Vunjak-Novakovic, G.; Hung, C.T.; Ateshian, G.A. High seeding density of human chondrocytes in agarose produces tissue-engineered cartilage approaching native mechanical and biochemical properties. J. Biomech. 2016, 49, 1909-1917. [CrossRef] [PubMed] 
47. Awad, H.A.; Wickham, M.Q.; Leddy, H.A.; Gimble, J.M.; Guilak, F. Chondrogenic differentiation of adipose-derived adult stem cells in agarose, alginate, and gelatin scaffolds. Biomaterials 2004, 25, 3211-3222. [CrossRef] [PubMed]

48. Sheehy, E.J.; Mesallati, T.; Vinardell, T.; Kelly, D.J. Engineering cartilage or endochondral bone: A comparison of different naturally derived hydrogels. Acta Biomater. 2015, 13, 245-253. [CrossRef]

49. Miao, Z.; Lu, Z.; Wu, H.; Liu, H.; Li, M.; Lei, D.; Zheng, L.; Zhao, J. Collagen, agarose, alginate, and Matrigel hydrogels as cell substrates for culture of chondrocytes in vitro: A comparative study. J. Cell. Biochem. 2018, 119, 7924-7933. [CrossRef]

50. Choi, B.; Kim, S.; Lin, B.; Wu, B.M.; Lee, M. Cartilaginous extracellular matrix-modified chitosan hydrogels for cartilage tissue engineering. ACS Appl. Mater. Interfaces 2014, 6, 20110-20121. [CrossRef]

51. Jin, R.; Moreira Teixeira, L.S.; Dijkstra, P.J.; Karperien, M.; van Blitterswijk, C.A.; Zhong, Z.Y.; Feijen, J. Injectable chitosan-based hydrogels for cartilage tissue engineering. Biomaterials 2009, 30, 2544-2551. [CrossRef]

52. Kim, S.H.; Yeon, Y.K.; Lee, J.M.; Chao, J.R.; Lee, Y.J.; Seo, Y.B.; Sultan, M.T.; Lee, O.J.; Lee, J.S.; Yoon, S.I.; et al. Precisely printable and biocompatible silk fibroin bioink for digital light processing 3D printing. Nat. Commun. 2018, 9, 1620. [CrossRef]

53. Irawan, V.; Sung, T.C.; Higuchi, A.; Ikoma, T. Collagen Scaffolds in Cartilage Tissue Engineering and Relevant Approaches for Future Development. Tissue Eng. Regen. Med. 2018, 15, 673-697. [CrossRef]

54. Kino-Oka, M.; Yashiki, S.; Ota, Y.; Mushiaki, Y.; Sugawara, K.; Yamamoto, T.; Takezawa, T.; Taya, M. Subculture of chondrocytes on a collagen type I-coated substrate with suppressed cellular dedifferentiation. Tissue Eng. 2005, 11, 597-608. [CrossRef]

55. Noth, U.; Rackwitz, L.; Heymer, A.; Weber, M.; Baumann, B.; Steinert, A.; Schutze, N.; Jakob, F.; Eulert, J. Chondrogenic differentiation of human mesenchymal stem cells in collagen type I hydrogels. J. Biomed. Mater. Res. Part A 2007, 83, 626-635. [CrossRef]

56. Bosnakovski, D.; Mizuno, M.; Kim, G.; Takagi, S.; Okumura, M.; Fujinaga, T. Chondrogenic differentiation of bovine bone marrow mesenchymal stem cells (MSCs) in different hydrogels: Influence of collagen type II extracellular matrix on MSC chondrogenesis. Biotechnol. Bioeng. 2006, 93, 1152-1163. [CrossRef]

57. Matsiko, A.; Gleeson, J.P.; O’Brien, F.J. Scaffold mean pore size influences mesenchymal stem cell chondrogenic differentiation and matrix deposition. Tissue Eng. Part A 2015, 21, 486-497. [CrossRef] [PubMed]

58. Jin, G.Z.; Kim, H.W. Effects of Type I Collagen Concentration in Hydrogel on the Growth and Phenotypic Expression of Rat Chondrocytes. Tissue Eng. Regen. Med. 2017, 14, 383-391. [CrossRef]

59. Lin, H.; Cheng, A.W.; Alexander, P.G.; Beck, A.M.; Tuan, R.S. Cartilage tissue engineering application of injectable gelatin hydrogel with in situ visible-light-activated gelation capability in both air and aqueous solution. Tissue Eng. Part A 2014, 20, 2402-2411. [CrossRef] [PubMed]

60. Sakai, S.; Hirose, K.; Taguchi, K.; Ogushi, Y.; Kawakami, K. An injectable, in situ enzymatically gellable, gelatin derivative for drug delivery and tissue engineering. Biomaterials 2009, 30, 3371-3377. [CrossRef] [PubMed]

61. Mouser, V.H.; Melchels, F.P.; Visser, J.; Dhert, W.J.; Gawlitta, D.; Malda, J. Yield stress determines bioprintability of hydrogels based on gelatin-methacryloyl and gellan gum for cartilage bioprinting. Biofabrication 2016, 8, 035003. [CrossRef]

62. Skaalure, S.C.; Dimson, S.O.; Pennington, A.M.; Bryant, S.J. Semi-interpenetrating networks of hyaluronic acid in degradable PEG hydrogels for cartilage tissue engineering. Acta Biomater. 2014, 10, 3409-3420. [CrossRef]

63. Goldshmid, R.; Cohen, S.; Shachaf, Y.; Kupershmit, I.; Sarig-Nadir, O.; Seliktar, D.; Wechsler, R. Steric Interference of Adhesion Supports In-Vitro Chondrogenesis of Mesenchymal Stem Cells on Hydrogels for Cartilage Repair. Sci. Rep. $2015,5,12607$. [CrossRef]

64. Wang, W.; Li, B.; Yang, J.; Xin, L.; Li, Y.; Yin, H.; Qi, Y.; Jiang, Y.; Ouyang, H.; Gao, C. The restoration of full-thickness cartilage defects with BMSCs and TGF-beta 1 loaded PLGA/fibrin gel constructs. Biomaterials 2010, 31, 8964-8973. [CrossRef]

65. Oliveira, A.S.; Seidi, O.; Ribeiro, N.; Colaço, R.; Serro, A.P. Tribomechanical Comparison between PVA Hydrogels Obtained Using Different Processing Conditions and Human Cartilage. Materials 2019, 12, 3413. [CrossRef]

66. Dashtdar, H.; Murali, M.R.; Abbas, A.A.; Suhaeb, A.M.; Selvaratnam, L.; Tay, L.X.; Kamarul, T. PVA-chitosan composite hydrogel versus alginate beads as a potential mesenchymal stem cell carrier for the treatment of focal cartilage defects. Knee Surg. Sports Traumatol. Arthrosc. J. ESSKA 2015, 23, 1368-1377. [CrossRef] [PubMed]

67. Medvedeva, E.V.; Grebenik, E.A.; Gornostaeva, S.N.; Telpuhov, V.I.; Lychagin, A.V.; Timashev, P.S.; Chagin, A.S. Repair of Damaged Articular Cartilage: Current Approaches and Future Directions. Int. J. Mol. Sci. 2018, 19, 2366. [CrossRef]

68. Tuan, R.S.; Boland, G.; Tuli, R. Adult mesenchymal stem cells and cell-based tissue engineering. Arthritis Res. 2003, 5, 32-45. [CrossRef]

69. Boeuf, S.; Richter, W. Chondrogenesis of mesenchymal stem cells: Role of tissue source and inducing factors. Stem Cell Res. Ther. 2010, 1, 31. [CrossRef]

70. Sakaguchi, Y.; Sekiya, I.; Yagishita, K.; Muneta, T. Comparison of human stem cells derived from various mesenchymal tissues: Superiority of synovium as a cell source. Arthritis Rheum. 2005, 52, 2521-2529. [CrossRef] [PubMed]

71. Horwitz, E.M.; Le Blanc, K.; Dominici, M.; Mueller, I.; Slaper-Cortenbach, I.; Marini, F.C.; Deans, R.J.; Krause, D.S.; Keating, A. Clarification of the nomenclature for MSC: The International Society for Cellular Therapy position statement. Cytotherapy 2005, 7, 393-395. [CrossRef] [PubMed]

72. Hass, R.; Kasper, C.; Bohm, S.; Jacobs, R. Different populations and sources of human mesenchymal stem cells (MSC): A comparison of adult and neonatal tissue-derived MSC. Cell Commun. Signal. 2011, 9, 12. [CrossRef] [PubMed] 
73. Kisiday, J.D.; Frisbie, D.D.; McIlwraith, C.W.; Grodzinsky, A.J. Dynamic compression stimulates proteoglycan synthesis by mesenchymal stem cells in the absence of chondrogenic cytokines. Tissue Eng. Part A 2009, 15, 2817-2824. [CrossRef]

74. Saw, K.Y.; Hussin, P.; Loke, S.C.; Azam, M.; Chen, H.C.; Tay, Y.G.; Low, S.; Wallin, K.L.; Ragavanaidu, K. Articular cartilage regeneration with autologous marrow aspirate and hyaluronic Acid: An experimental study in a goat model. Arthrosc. J. Arthrosc. Relat. Surg. Publ. Arthrosc. Assoc. North. Am. Int. Arthrosc. Assoc. 2009, 25, 1391-1400. [CrossRef] [PubMed]

75. Lee, K.B.; Hui, J.H.; Song, I.C.; Ardany, L.; Lee, E.H. Injectable mesenchymal stem cell therapy for large cartilage defects-A porcine model. Stem Cells 2007, 25, 2964-2971. [CrossRef]

76. Desando, G.; Bartolotti, I.; Cavallo, C.; Schiavinato, A.; Secchieri, C.; Kon, E.; Filardo, G.; Paro, M.; Grigolo, B. Short-Term Homing of Hyaluronan-Primed Cells: Therapeutic Implications for Osteoarthritis Treatment. Tissue Eng. Part C Methods 2018, 24, 121-133. [CrossRef]

77. Chiang, E.R.; Ma, H.L.; Wang, J.P.; Liu, C.L.; Chen, T.H.; Hung, S.C. Allogeneic Mesenchymal Stem Cells in Combination with Hyaluronic Acid for the Treatment of Osteoarthritis in Rabbits. PLoS ONE 2016, 11, e0149835. [CrossRef] [PubMed]

78. Suhaeb, A.M.; Naveen, S.; Mansor, A.; Kamarul, T. Hyaluronic acid with or without bone marrow derived-mesenchymal stem cells improves osteoarthritic knee changes in rat model: A preliminary report. Indian J. Exp. Biol. 2012, 50, 383-390.

79. Sato, M.; Uchida, K.; Nakajima, H.; Miyazaki, T.; Guerrero, A.R.; Watanabe, S.; Roberts, S.; Baba, H. Direct transplantation of mesenchymal stem cells into the knee joints of Hartley strain guinea pigs with spontaneous osteoarthritis. Arthritis Res. 2012, 14, R31. [CrossRef] [PubMed]

80. Mokbel, A.N.; El Tookhy, O.S.; Shamaa, A.A.; Rashed, L.A.; Sabry, D.; El Sayed, A.M. Homing and reparative effect of intraarticular injection of autologus mesenchymal stem cells in osteoarthritic animal model. BMC Musculoskelet. Disord. 2011, 12, 259. [CrossRef]

81. Murphy, J.M.; Fink, D.J.; Hunziker, E.B.; Barry, F.P. Stem cell therapy in a caprine model of osteoarthritis. Arthritis Rheum. 2003, 48, 3464-3474. [CrossRef]

82. Lee, K.B.; Wang, V.T.; Chan, Y.H.; Hui, J.H. A novel, minimally-invasive technique of cartilage repair in the human knee using arthroscopic microfracture and injections of mesenchymal stem cells and hyaluronic acid-a prospective comparative study on safety and short-term efficacy. Ann. Acad Med. Singap. 2012, 41, 511-517.

83. Pascual-Garrido, C.; Aisenbrey, E.A.; Rodriguez-Fontan, F.; Payne, K.A.; Bryant, S.J.; Goodrich, L.R. Photopolymerizable Injectable Cartilage Mimetic Hydrogel for the Treatment of Focal Chondral Lesions: A Proof of Concept Study in a Rabbit Animal Model. Am. J. Sports Med. 2019, 47, 212-221. [CrossRef]

84. Choi, S.M.; Lee, K.M.; Ryu, S.B.; Park, Y.J.; Hwang, Y.G.; Baek, D.; Choi, Y.; Park, K.H.; Park, K.D.; Lee, J.W. Enhanced articular cartilage regeneration with SIRT1-activated MSCs using gelatin-based hydrogel. Cell Death Dis. 2018, 9, 866. [CrossRef]

85. Kim, J.E.; Lee, S.M.; Kim, S.H.; Tatman, P.; Gee, A.O.; Kim, D.H.; Lee, K.E.; Jung, Y.; Kim, S.J. Effect of self-assembled peptidemesenchymal stem cell complex on the progression of osteoarthritis in a rat model. Int. J. Nanomed. 2014, 9 (Suppl. 1), $141-157$. [CrossRef]

86. McIlwraith, C.W.; Frisbie, D.D.; Rodkey, W.G.; Kisiday, J.D.; Werpy, N.M.; Kawcak, C.E.; Steadman, J.R. Evaluation of intraarticular mesenchymal stem cells to augment healing of microfractured chondral defects. Arthrosc. J. Arthrosc. Relat. Surg. Publ. Arthrosc. Assoc. North Am. Int. Arthrosc. Assoc. 2011, 27, 1552-1561. [CrossRef] [PubMed]

87. Pipino, G.; Risitano, S.; Alviano, F.; Wu, E.J.; Bonsi, L.; Vaccarisi, D.C.; Indelli, P.F. Microfractures and hydrogel scaffolds in the treatment of osteochondral knee defects: A clinical and histological evaluation. J. Clin. Orthop. Trauma 2019, 10, 67-75. [CrossRef] [PubMed]

88. Lv, X.; He, J.; Zhang, X.; Luo, X.; He, N.; Sun, Z.; Xia, H.; Liu, V.; Zhang, L.; Lin, X.; et al. Comparative Efficacy of Autologous Stromal Vascular Fraction and Autologous Adipose-Derived Mesenchymal Stem Cells Combined With Hyaluronic Acid for the Treatment of Sheep Osteoarthritis. Cell Transpl. 2018, 27, 1111-1125. [CrossRef]

89. Feng, C.; Luo, X.; He, N.; Xia, H.; Lv, X.; Zhang, X.; Li, D.; Wang, F.; He, J.; Zhang, L.; et al. Efficacy and Persistence of Allogeneic Adipose-Derived Mesenchymal Stem Cells Combined with Hyaluronic Acid in Osteoarthritis After Intra-articular Injection in a Sheep Model. Tissue Eng. Part A 2018, 24, 219-233. [CrossRef] [PubMed]

90. Sevastianov, V.I.; Basok, Y.B.; Kirsanova, L.A.; Grigoriev, A.M.; Kirillova, A.D.; Nemets, E.A.; Subbot, A.M.; Gautier, S.V. A Comparison of the Capacity of Mesenchymal Stromal Cells for Cartilage Regeneration Depending on Collagen-Based Injectable Biomimetic Scaffold Type. Life 2021, 11, 756. [CrossRef] [PubMed]

91. Jia, Z.; Zhu, F.; Li, X.; Liang, Q.; Zhuo, Z.; Huang, J.; Duan, L.; Xiong, J.; Wang, D. Repair of osteochondral defects using injectable chitosan-based hydrogel encapsulated synovial fluid-derived mesenchymal stem cells in a rabbit model. Mater. Sci. Eng. C Mater. Biol. Appl. 2019, 99, 541-551. [CrossRef]

92. Wu, K.C.; Chang, Y.H.; Liu, H.W.; Ding, D.C. Transplanting human umbilical cord mesenchymal stem cells and hyaluronate hydrogel repairs cartilage of osteoarthritis in the minipig model. Ci Ji Yi Xue Za Zhi 2019, 31, 11-19. [CrossRef]

93. Li, J.; Huang, Y.; Song, J.; Li, X.; Zhang, X.; Zhou, Z.; Chen, D.; Ma, P.X.; Peng, W.; Wang, W.; et al. Cartilage regeneration using arthroscopic flushing fluid-derived mesenchymal stem cells encapsulated in a one-step rapid cross-linked hydrogel. Acta Biomater. 2018, 79, 202-215. [CrossRef]

94. Steinert, A.F.; Noth, U.; Tuan, R.S. Concepts in gene therapy for cartilage repair. Injury 2008, 39 (Suppl. 1), S97-S113. [CrossRef] [PubMed] 
95. Indrawattana, N.; Chen, G.; Tadokoro, M.; Shann, L.H.; Ohgushi, H.; Tateishi, T.; Tanaka, J.; Bunyaratvej, A. Growth factor combination for chondrogenic induction from human mesenchymal stem cell. Biochem. Biophys. Res. Commun. 2004, 320, 914-919. [CrossRef]

96. Vayas, R.; Reyes, R.; Arnau, M.R.; Évora, C.; Delgado, A. Injectable Scaffold for Bone Marrow Stem Cells and Bone Morphogenetic Protein-2 to Repair Cartilage. Cartilage 2021, 12, 293-306. [CrossRef] [PubMed]

97. Deng, Y.; Sun, A.X.; Overholt, K.J.; Yu, G.Z.; Fritch, M.R.; Alexander, P.G.; Shen, H.; Tuan, R.S.; Lin, H. Enhancing chondrogenesis and mechanical strength retention in physiologically relevant hydrogels with incorporation of hyaluronic acid and direct loading of TGF- $\beta$. Acta Biomater. 2019, 83, 167-176. [CrossRef]

98. Jooybar, E.; Abdekhodaie, M.J.; Alvi, M.; Mousavi, A.; Karperien, M.; Dijkstra, P.J. An injectable platelet lysate-hyaluronic acid hydrogel supports cellular activities and induces chondrogenesis of encapsulated mesenchymal stem cells. Acta Biomater. 2019, 83, 233-244. [CrossRef]

99. Xia, W.; Jin, Y.Q.; Kretlow, J.D.; Liu, W.; Ding, W.; Sun, H.; Zhou, G.; Zhang, W.; Cao, Y. Adenoviral transduction of hTGF-beta1 enhances the chondrogenesis of bone marrow derived stromal cells. Biotechnol. Lett. 2009, 31, 639-646. [CrossRef] [PubMed]

100. Wang, X.; Li, Y.; Han, R.; He, C.; Wang, G.; Wang, J.; Zheng, J.; Pei, M.; Wei, L. Demineralized bone matrix combined bone marrow mesenchymal stem cells, bone morphogenetic protein-2 and transforming growth factor-beta3 gene promoted pig cartilage defect repair. PLoS ONE 2014, 9, e116061. [CrossRef]

101. Cao, L.; Yang, F.; Liu, G.; Yu, D.; Li, H.; Fan, Q.; Gan, Y.; Tang, T.; Dai, K. The promotion of cartilage defect repair using adenovirus mediated Sox9 gene transfer of rabbit bone marrow mesenchymal stem cells. Biomaterials 2011, 32, 3910-3920. [CrossRef]

102. Venkatesan, J.K.; Ekici, M.; Madry, H.; Schmitt, G.; Kohn, D.; Cucchiarini, M. SOX9 gene transfer via safe, stable, replicationdefective recombinant adeno-associated virus vectors as a novel, powerful tool to enhance the chondrogenic potential of human mesenchymal stem cells. Stem Cell Res. Ther. 2012, 3, 22. [CrossRef]

103. Lu, C.H.; Yeh, T.S.; Yeh, C.L.; Fang, Y.H.; Sung, L.Y.; Lin, S.Y.; Yen, T.C.; Chang, Y.H.; Hu, Y.C. Regenerating cartilages by engineered ASCs: Prolonged TGF-beta3/BMP-6 expression improved articular cartilage formation and restored zonal structure. Mol. Ther. J. Am. Soc. Gene Ther. 2014, 22, 186-195. [CrossRef] [PubMed]

104. Lee, J.M.; Im, G.I. SOX trio-co-transduced adipose stem cells in fibrin gel to enhance cartilage repair and delay the progression of osteoarthritis in the rat. Biomaterials 2012, 33, 2016-2024. [CrossRef] [PubMed]

105. Li, W.J.; Tuli, R.; Okafor, C.; Derfoul, A.; Danielson, K.G.; Hall, D.J.; Tuan, R.S. A three-dimensional nanofibrous scaffold for cartilage tissue engineering using human mesenchymal stem cells. Biomaterials 2005, 26, 599-609. [CrossRef] [PubMed]

106. Leng, P.; Ding, C.R.; Zhang, H.N.; Wang, Y.Z. Reconstruct large osteochondral defects of the knee with hIGF-1 gene enhanced Mosaicplasty. Knee 2012, 19, 804-811. [CrossRef]

107. Venkatesan, J.K.; Gardner, O.; Rey-Rico, A.; Eglin, D.; Alini, M.; Stoddart, M.J.; Cucchiarini, M.; Madry, H. Improved Chondrogenic Differentiation of rAAV SOX9-Modified Human MSCs Seeded in Fibrin-Polyurethane Scaffolds in a Hydrodynamic Environment. Int. J. Mol. Sci. 2018, 19, 2635. [CrossRef]

108. Freyria, A.M.; Mallein-Gerin, F. Chondrocytes or adult stem cells for cartilage repair: The indisputable role of growth factors. Injury 2012, 43, 259-265. [CrossRef]

109. O'Shea, T.M.; Miao, X. Bilayered scaffolds for osteochondral tissue engineering. Tissue Eng. Part B Rev. 2008, 14, 447-464. [CrossRef] [PubMed]

110. Shimomura, K.; Moriguchi, Y.; Murawski, C.D.; Yoshikawa, H.; Nakamura, N. Osteochondral tissue engineering with biphasic scaffold: Current strategies and techniques. Tissue Eng. Part B Rev. 2014, 20, 468-476. [CrossRef]

111. Ricci, M.; Tradati, D.; Maione, A.; Uboldi, F.M.; Usellini, E.; Berruto, M. Cell-free osteochondral scaffolds provide a substantial clinical benefit in the treatment of osteochondral defects at a minimum follow-up of 5 years. J. Exp. Orthop. 2021, 8, 62. [CrossRef] [PubMed] 